\title{
TECTONOPHYSICS
}

\section{Rayleigh wave group velocity tomography in the Aegean area}

\author{
E.E. Karagianni ${ }^{\text {a } *}$, D.G. Panagiotopoulos ${ }^{\text {a }}$, G.F. Panza ${ }^{\text {b }}$, P. Suhadolc ${ }^{\text {, }}$, \\ C.B. Papazachos ${ }^{\text {a }}$, B.C. Papazachos ${ }^{\text {a }}$, A. Kiratzi ${ }^{\mathrm{a}}$, D. Hatzfeld ${ }^{\mathrm{c}}$, \\ K. Makropoulos ${ }^{d}, K$. Priestley ${ }^{\mathrm{e}}$, A. Vuan $^{\mathrm{f}}$ \\ ${ }^{\mathrm{a}}$ Geophysical Laboratory, Aristotle University of Thessaloniki, P.O. Box 352-1, GR 54006 Thessaloniki, Greece \\ ${ }^{\mathrm{b}}$ Department of Earth Sciences, University of Trieste, Trieste, Italy \\ ${ }^{\mathrm{c}}$ Laboratoire de Geophysique Interne et Tectonophysique, Grenoble, France \\ ${ }^{\mathrm{d}}$ Department of Geophysics, University of Athens, Athens, Greece \\ ${ }^{\mathrm{e}}$ Bullard Laboratory, Cambridge, UK \\ ${ }^{\mathrm{f}}$ Dipartimento di Geofisica della Litosfera, Oss. Geofisico di Trieste, Trieste, Italy
}

Received 27 October 2000; received in revised form 18 July 2001; accepted 15 June 2002

\begin{abstract}
Data from a large-scale experiment which took place in Greece during the period January-July 1997 have been used to investigate the structure of the Aegean area using surface waves. During this experiment, 30 seismic broadband instruments were deployed throughout the whole Greek area. Additional data during the period 1996-2000 from other temporary networks have been included in the dataset. One hundred eighty-five events with magnitudes $4.0 \leq M_{\mathrm{w}} \leq 5.5$ recorded by these stations have been collected and processed. The individual dispersion curves of the group velocity of Rayleigh waves for each source-station path have been calculated, producing more than 700 paths covering the studied region. These curves have been used to determine Rayleigh group velocity maps using a 2D-tomography method. On the basis of a regionalization of the dispersion measurements, local averaged dispersion curves have been obtained and non-linearly inverted to obtain models of shear-wave velocity versus depth. Since the dispersion curves in the period range $5 \mathrm{~s} \leq T \leq 30 \mathrm{~s}$ are mostly affected by the crustal structure, the model velocities are estimated down to a depth of approximately $35-45 \mathrm{~km}$. The results from the non-linear Hedhehog inversion as applied to a few local dispersion curves show a crustal thickness of approximately $32 \mathrm{~km}$ for the Northern Aegean Sea, and a relatively thin crust of approximately $22-24 \mathrm{~km}$ for the Southern Aegean Sea.
\end{abstract}

(C) 2002 Elsevier Science B.V. All rights reserved.

Keywords: Aegean area; Rayleigh waves; Group velocity; Tomography; Hedgehog inversion

\footnotetext{
* Corresponding author. Tel.: +30-31-998535; fax: +30-31998528.

E-mail address: karagian@lemnos.geo.auth.gr (E.E. Karagianni).
}

\section{Introduction}

The region of the Aegean area (in this paper, this term includes the Aegean Sea, continental Greece and surrounding areas) lies at the convergence zone of the Eurasian and African lithospheric plates with several smaller plates in between. The Eastern Mediterranean plate is subducting under the Aegean, which has been 
recognized to form a separate Aegean microplate moving at an average velocity of $40 \mathrm{~mm} /$ year towards the southwest with respect to Eurasia (McKenzie, 1972; Jackson, 1994; Papazachos et al., 1998; Papazachos, 1999). This subduction results in the formation of a well-defined Benioff zone (Papazachos and Comninakis, 1971; Caputo et al., 1970; McKenzie, 1970, 1978; Le Pichon and Angelier, 1979). Moreover, it is the main reason behind the high tectonic activity in this area, with volcanic activity (Georgalas, 1962), magnetic anomalies and positive isostatic anomalies (e.g.
Fleischer, 1964; Vogt and Higgs, 1969; Makris, 1976), high heat flow (e.g. Fytikas et al., 1985) and high attenuation of seismic energy (e.g. Papazachos and Comninakis, 1971; Hashida et al., 1988). Fig. 1 shows the main topographic features of tectonic origin in the studied area (Papazachos and Papazachou, 1997). The most characteristic features of subduction zones are observed in the Southern Aegean along the Hellenic arc, with an outer-arc trench (the Hellenic trench), the Hellenides mountain range, an inner-arc volcanic arc, and a back-arc sedimentary arc (Southern Aegean

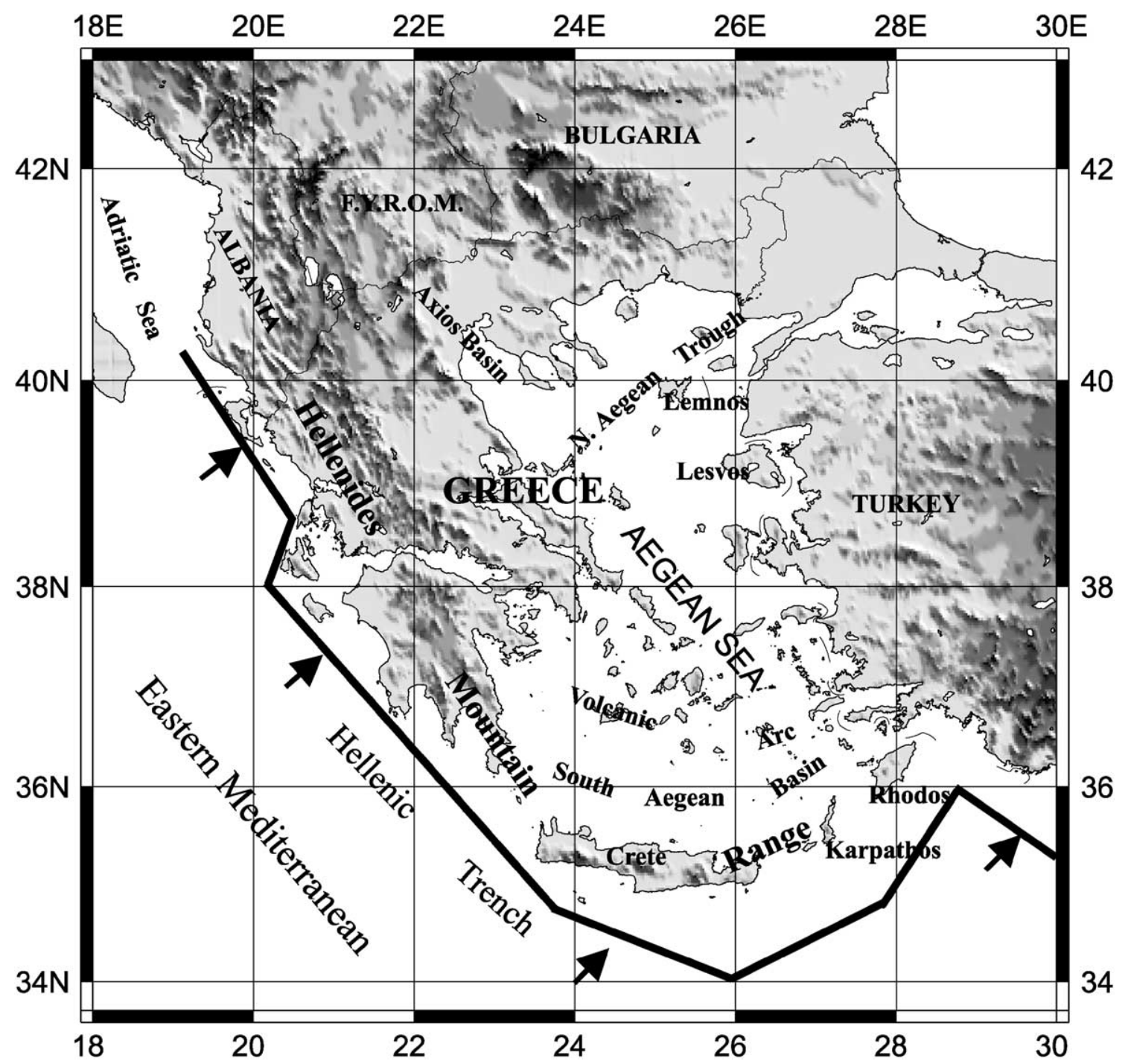

Fig. 1. Main topographic features of tectonic origin of the region under study. 
basin). The most dominant feature in the North Aegean is the NE-SW trending trench (North Aegean trough) which represents the continuation of the dextral strike-slip of the North Anatolian fault in the Aegean area.

The velocity structure of the crust and upper mantle in this area has been extensively studied. Travel times of body waves generated by either earthquakes (Panagiotopoulos, 1984; Panagiotopulos and Papazachos, 1985; Plomerova et al., 1989) or by explosions (Makris, 1973, 1978; Delibasis et al., 1988; Voulgaris, 1991) have been used, as well as dispersion of surface waves (Papazachos et al., 1967; Calcagnile et al., 1982; Kalogeras, 1993) and gravity data (Makris, 1976; Chailas et al., 1993; Papazachos, 1994). In general, strong variations in the crustal structure characterize the study region. A thin crust of the order of $20-30 \mathrm{~km}$ has been proposed in the back-arc area, whereas a large crustal thickness $(40-47 \mathrm{~km})$ has been proposed along the Hellenides mountain range. The crust has a normal thickness $(28-37 \mathrm{~km})$ in the eastern part of the Greek peninsula, in the Northern and Central Aegean, in Western Turkey and in Crete. An overall description of the lithosphere and upper mantle is given by early tomographic studies (Spakman, 1986; Spakman et al., 1988, 1993; Ligdas et al., 1990; Ligdas and Main, 1991; Drakatos, 1989; Drakatos et al., 1989; Christodoulou and Hatzfeld, 1988; Ligdas and Lees, 1993; Papazachos et al., 1995). Recently, Papazachos and Nolet (1997), using travel time data from local earthquakes in Greece and surrounding areas, presented detailed results for the structure of the Aegean lithosphere.

The purpose of this study is to present surface wave tomography of the crustal structure in the Aegean area. The seismic surface wave group velocities have been chosen as initial data, because it is relatively easy to cover the Aegean area with a dense distribution of ray paths, given the quantity of earthquakes and the highquality digital seismic station network installed in the area. For selected periods $(6,10,14,19,24$ and $28 \mathrm{~s})$, smooth group velocity images were obtained with a spatial resolution which depend on the distribution of the earthquakes paths. In the period interval and distances range considered, group velocities are not significantly sensitive to the source phase, as sourcegroup time corrections are generally small and may be neglected for group velocity measurements at periods less than $75 \mathrm{~s}$ and source depths less than $25 \mathrm{~km}$ (Levshin et al., 1999). Several synthetic tests that were performed across the Eurasian continent (Levshin et al., 1999) to estimate the bias caused by uncorrected source-group time, showed that the perturbations produced by uncorrected source group time in the inversion of Rayleigh wave group velocity data are generally very small (less than 1\%). Appreciable perturbations $(1-2 \%)$ appear only at the borders of the area where the path coverage is poor at periods much larger than those considered in our work $(\geq 50$ s). In the present study, the obtained tomographic images exhibit clear lateral variations up to $25-30 \%$, so the source group time correction is not expected to introduce significant bias to the group velocity measurements.

Local dispersion curves extracted from the tomographic results have been inverted using a non-linear inversion procedure to obtain models of S-wave velocity versus depth (e.g. Keilis-Borok and Yanovskaya, 1967).

\section{Data and dispersion measurements}

Data from a large-scale experiment, which took place in Greece during the period January to July 1997, have been used. During this project, 30 digital three-component recorders (mainly Titan and Reftek) were installed all over the Greek area for a period of 6 months in order to record teleseismic and regional earthquakes. The equipment consisted of Lennartz LE5S (High-Pass 5 s), Guralp CMG-40 (High Pass 20 or 60 s), and Guralp CMG-3 (High Pass 60 or 100 s) seismometers, and Reftek 72A06 and Agecodagis TitanDat data loggers, which recorded continuously at a sample frequency of 62.5 or $50 \mathrm{sps}$. The time was calibrated by GPS receivers in all stations. Instruments were installed in permanent stations of the Seismological Network of Thessaloniki, of the National Observatory of Athens, and in temporary shelters, where the seismometers were protected from temperature variations. All the stations were visited every month to collect and check the data. Because of poor weather conditions, especially during the winter, microseismic noise was very strong during some time periods, for which the signal-to-noise ratio was too low. In total, about $180 \mathrm{~Gb}$ of raw data were recorded. 
A description of this experiment is also given by Hatzfeld et al. (submitted for publication). We also used data, from the recent Izmit, Turkey earthquake $\left(17 / \mathrm{Aug} / 1999 M_{\mathrm{w}}=7.4\right)$ and several of its aftershocks, as well as from the Athens earthquake (07/Sept/1999 $\left.M_{\mathrm{w}}=5.9\right)$, recorded at the portable stations installed in the regions of Asvestochori (Thessaloniki) and Athens, by the Geophysical Laboratory of Aristotle University of Thessaloniki. Furthermore, some seismic records recorded by stations installed in the South Aegean Sea by the GeoForschungsNetz of the GeoForschungsZentrum (Potsdam, Germany) were included. The locations and the magnitudes of the earth- quakes related to these three last datasets have been relocated, and are reported in the catalogue of the Central seismological station of University of Thessaloniki and the National Observatory of Athens. The origin time of these events has been taken from the same catalogue. In total 232 events within the area defined by $34-42^{\circ} \mathrm{N}$ and $19-31^{\circ} \mathrm{E}$ and recorded by the broad-band stations of the above temporary networks (Table 1) have been selected. We selected only earthquakes with hypocentral depth less than $30 \mathrm{~km}$, and magnitude $4.0 \leq M_{\mathrm{w}} \leq 5.5$, except for two earthquakes with $M_{\mathrm{w}}=7.4$ and 6.4 , respectively, and two others with $M_{\mathrm{w}}=5.9$. However, the original database is

Table 1

Parameters of the temporary stations used in the present study

\begin{tabular}{|c|c|c|c|c|c|}
\hline Code & Coordinates & Elevation & Seismometer & Recorder & Location \\
\hline AGG & $39.018 \mathrm{~N} 22.326 \mathrm{E}$ & 540 & CMGT3381 & TITANDAT & AG GEORGIOS \\
\hline ALN & $40.973 \mathrm{~N} 25.792 \mathrm{E}$ & 377 & CMGT3384 & TITANDAT & ALEXANDROUPOLI \\
\hline ANA & $39.745 \mathrm{~N} 22.688 \mathrm{E}$ & 1000 & LE27 & TITANDAT & ANATOLI \\
\hline AND & $37.906 \mathrm{~N} 24.743 \mathrm{E}$ & 130 & CMGT4240 & REFTEK & ANDROS \\
\hline ANT & $38.380 \mathrm{~N} 22.632 \mathrm{E}$ & 30 & LE34 & TITANDAT & ANTIKIRA \\
\hline DRA & $41.204 \mathrm{~N} 24.017 \mathrm{E}$ & 300 & LE38 & TITANDAT & DRAMA \\
\hline FNA & $40.782 \mathrm{~N} 21.384 \mathrm{E}$ & 790 & CMGT3385 & TITANDAT & FLORINA \\
\hline HIO & $38.256 \mathrm{~N} 26.040 \mathrm{E}$ & 200 & CMGT4156 & REFTEK & HIOS \\
\hline KAP & $35.550 \mathrm{~N} 27.174 \mathrm{E}$ & 270 & CMGT4068 & REFTEK & KARPATHOS \\
\hline KNT & $41.167 \mathrm{~N} 22.900 \mathrm{E}$ & 430 & CMGT4067 & REFTEK & KENTRIKO \\
\hline KOS & $36.842 \mathrm{~N} 27.205 \mathrm{E}$ & 390 & CMGT4158 & REFTEK & KOS \\
\hline KZN & $40.305 \mathrm{~N} 21.784 \mathrm{E}$ & 700 & LE13 & TITANDAT & KOZANI \\
\hline KRA & $37.346 \mathrm{~N} 23.154 \mathrm{E}$ & 0 & LE16 & TITANDAT & KRANIDI \\
\hline PRK & $39.246 \mathrm{~N} 26.265 \mathrm{E}$ & 80 & CMGT3383 & TITANDAT & LESVOS \\
\hline LOS & $39.952 \mathrm{~N} 25.164 \mathrm{E}$ & 190 & CMGT3382 & TITANDAT & LIMNOS \\
\hline LIT & $40.100 \mathrm{~N} 22.489 \mathrm{E}$ & 550 & CMGT4336 & REFTEK & LITOCHORO \\
\hline MAR & $38.705 \mathrm{~N} 23.586 \mathrm{E}$ & 290 & LE71 & TITANDAT & MARKADES \\
\hline MIL & $36.679 \mathrm{~N} 24.441 \mathrm{E}$ & 30 & CMGT4070 & REFTEK & MILOS \\
\hline APE & $37.073 \mathrm{~N} 25.523 \mathrm{E}$ & 650 & CMGT4072 & REFTEK & NAXOS \\
\hline PTL & $38.047 \mathrm{~N} 23.964 \mathrm{E}$ & 530 & CMGT362 & REFTEK & PENTELI \\
\hline ARG & $36.088 \mathrm{~N} 28.022 \mathrm{E}$ & 73 & CMGT3257 & REFTEK & RHODOS \\
\hline SMG & $37.704 \mathrm{~N} 26.838 \mathrm{E}$ & 380 & CMGT3256 & REFTEK & SAMOS \\
\hline SKI & $38.868 \mathrm{~N} 24.572 \mathrm{E}$ & 80 & CMGT4161 & REFTEK & SKIROS \\
\hline SKO & $39.112 \mathrm{~N} 23.749 \mathrm{E}$ & 400 & CMGT4337 & REFTEK & SKOPELOS \\
\hline THE & $40.632 \mathrm{~N} 22.963 \mathrm{E}$ & 120 & TELEDYNE & REFTEK & THESSALONII \\
\hline VAV & $40.427 \mathrm{~N} 23.332 \mathrm{E}$ & 950 & CMGT4071 & REFTEK & VAVDOS \\
\hline VLI & $36.718 \mathrm{~N} 22.948 \mathrm{E}$ & 240 & CMGT360 & REFTEK & VELIES \\
\hline AGB & $40.650 \mathrm{~N} 23.100 \mathrm{E}$ & 296 & CMGT4831 & REFTEK & ASVESTOXORI \\
\hline SEP & $38.004 \mathrm{~N} 23.717 \mathrm{E}$ & 97 & CMGT4588 & REFTEK & ATHINA \\
\hline MAN & $38.076 \mathrm{~N} 23.499 \mathrm{E}$ & 156 & $\mathrm{CMGT}_{4831^{\mathrm{a}}}$ & REFTEK & ATHINA \\
\hline KYR & $38.092 \mathrm{~N} 23.618 \mathrm{E}$ & 189 & CMGT4830 & REFTEK & ATHINA \\
\hline KRIS & $35.178 \mathrm{~N} 25.503 \mathrm{E}$ & 850 & STS2 & REFTEK & CRETE \\
\hline SANT & $36.371 \mathrm{~N} 25.459 \mathrm{E}$ & 540 & STS2 & REFTEK & SANTORINI \\
\hline ALG & $35.355 \mathrm{~N} 23.690 \mathrm{E}$ & 0 & STS2 & REFTEK & CHANIA \\
\hline GVD & $34.849 \mathrm{~N} 24.090 \mathrm{E}$ & 60 & STS2 & REFTEK & GAYDOS \\
\hline
\end{tabular}

a These stations were in used for different periods of time. 
reduced because of the low signal to noise ratio at some records. Therefore, in order to avoid some unreliable dispersion curves only 185 events have been used in this work. The epicenters of earthquakes (denoted with open circles) as well as the locations of the portable stations used in this study are shown in Fig. 2.

For each station-earthquake pair, an observed group velocity of Rayleigh waves has been estimated applying the Frequency Time Analysis (FTAN) method to the vertical component of motion (Levshin et al., 1972, 1989, 1992). This method is based on a frequency-time representation of a seismic signal, obtained by passing an input seismic record through a system of narrow frequency band Gaussian filters and representing the amplitudes of the envelopes and instant phases of filter outputs as a 2D complex function of time and period.

An example of the FTAN processing, for the determination of group velocity as applied to an earthquake which occurred near the Zante Island (SouthWest Greece) and recorded by the station APE (Central Aegean Sea), is shown in Fig. 3.

The process has been applied for each stationearthquake pair. As the mean averaging path length is of the order of $400 \mathrm{~km}$, the Rayleigh waves have been well-recorded in the period range from 5 to $30 \mathrm{~s}$. Around 700 observed Rayleigh-wave group velocities have been determined along different ray paths covering the region under study. The coverage of the study

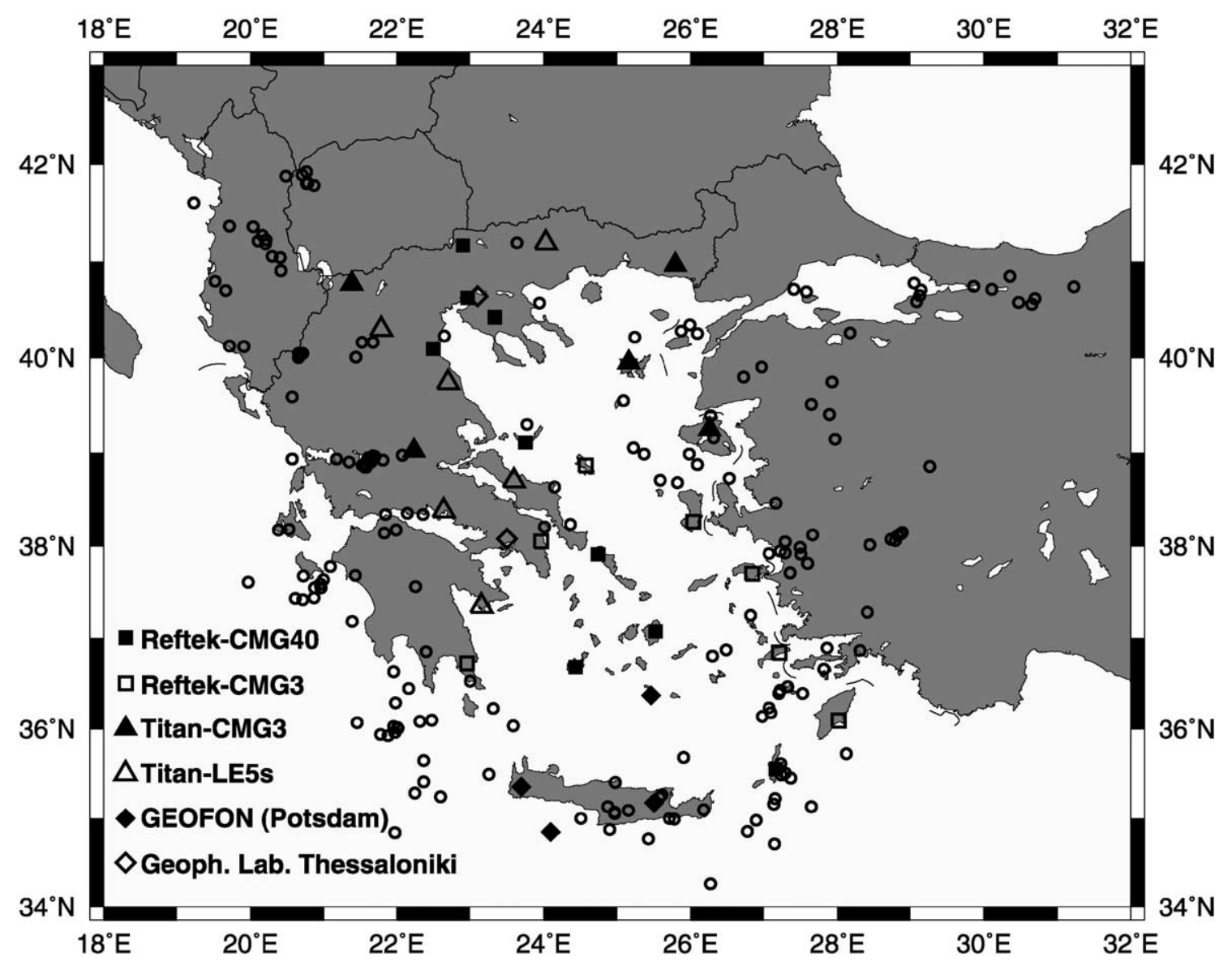

Fig. 2. Map of the epicenters (denoted with open circles) of the events which were used in the present study and the locations of the portable stations. 

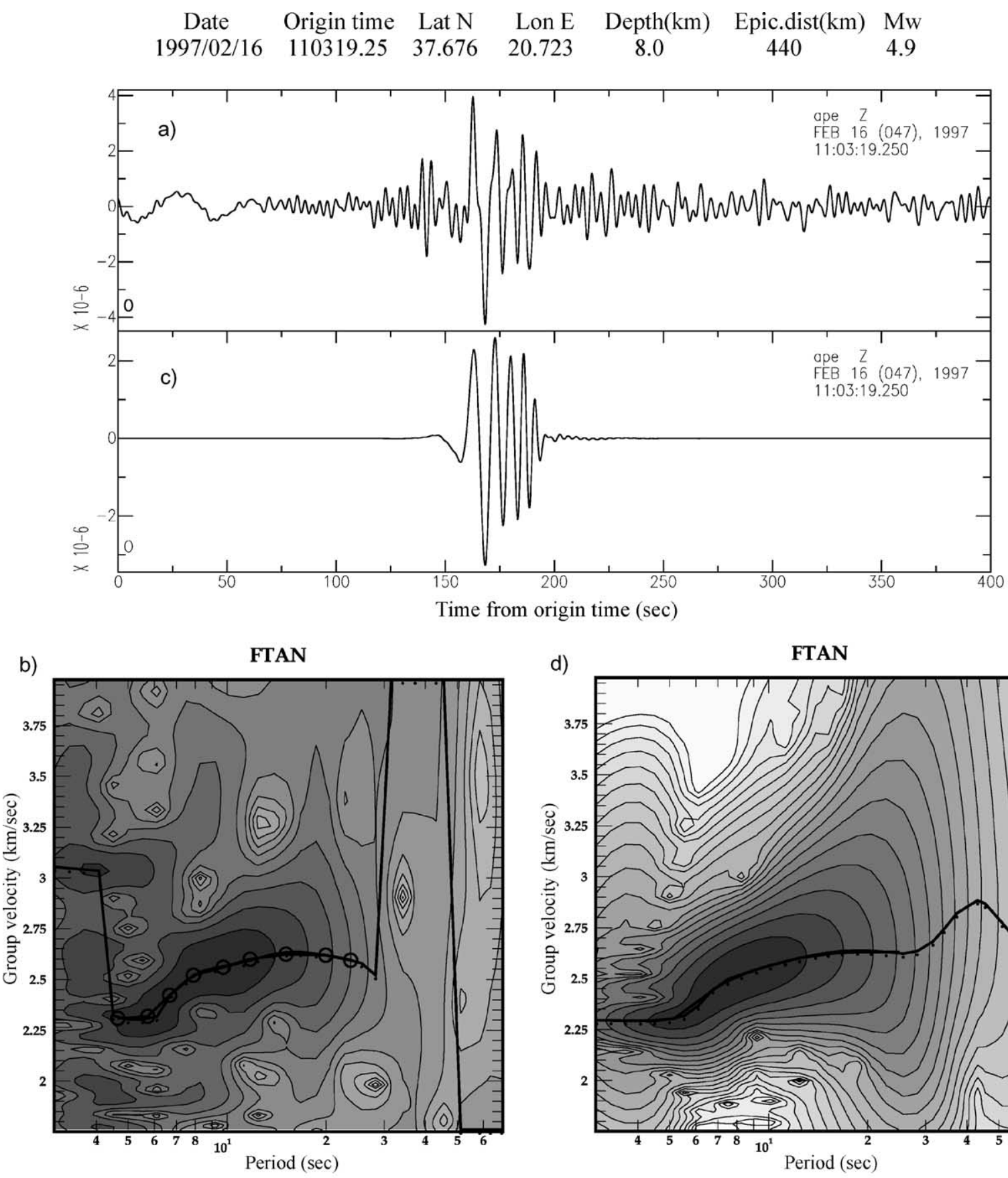

d) $\quad$ FTAN

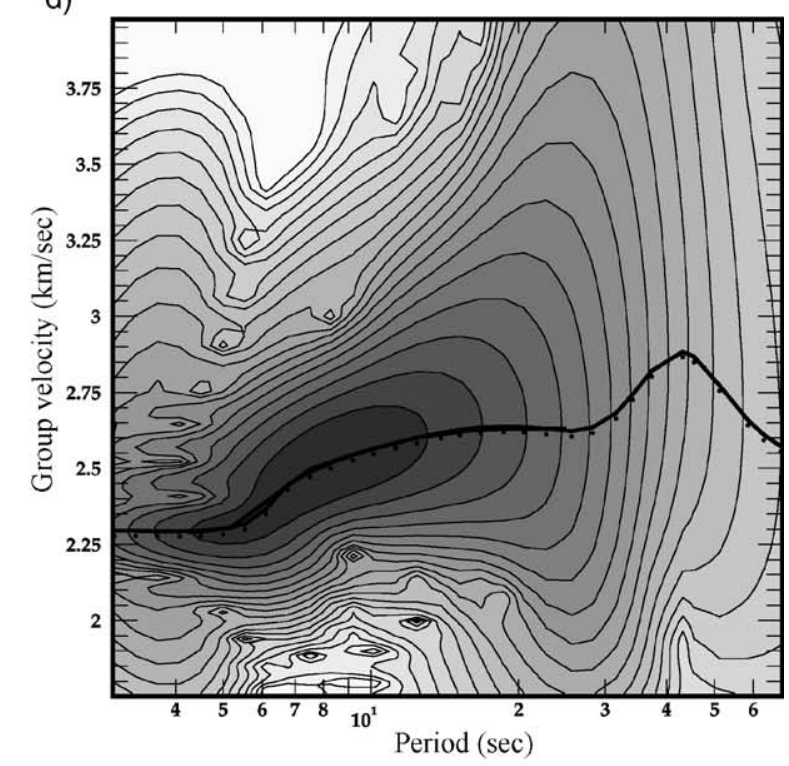

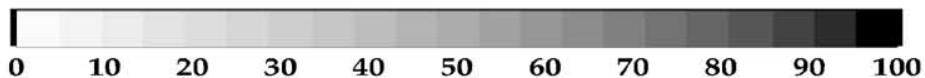

Fig. 3. Example of FTAN processing for the vertical component of the station APE for an event in SW Greece. (a) Input raw signal. (b) FTANdiagram of (a). The isolines of the signal power of the raw signal are presented with a 4-dB increment. The group velocity curve of the fundamental mode is identified by open circles. (c) Phase equalised and time variable filtered signal. (d) FTAN-diagram of (c). 


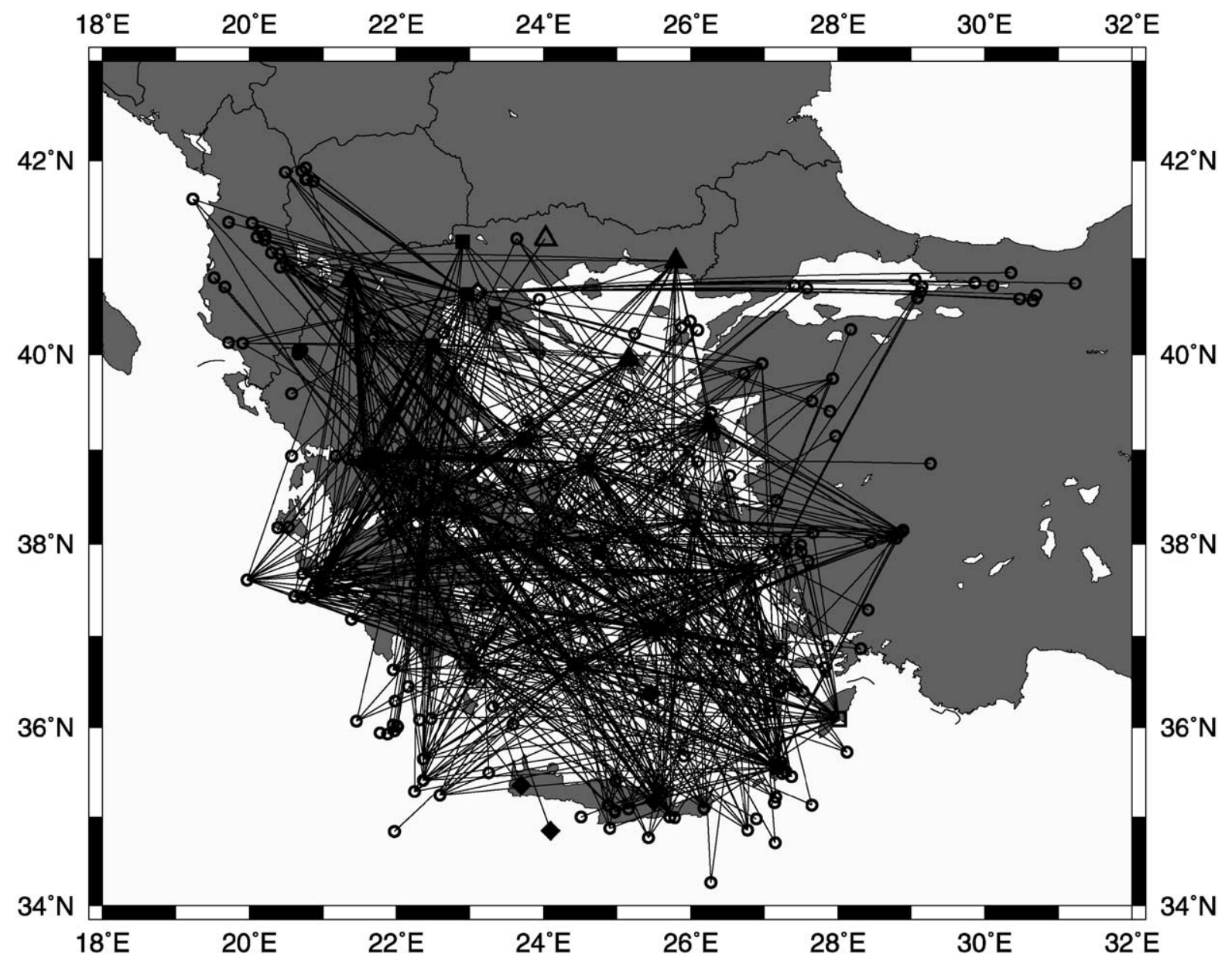

Fig. 4. Path coverage for this study at $10 \mathrm{~s}$.

area for the period of $10 \mathrm{~s}$ is shown in Fig. 4. As can be observed the azimuthal distribution of the paths is quite uniform and the coverage is satisfactory, especially in the central Aegean area.

\section{Tomographic method}

To construct the group velocity tomographic maps, we have applied a generalized 2D-linear inversion program developed by Ditmar and Yanovskaya (1987) and Yanovskaya and Ditmar (1990). The method of Yanovskaya and Ditmar is a generalization to two dimensions of the classical one-dimensional method of Backus and Gilbert (1968). The tomographic method estimates a group velocity map $U(x)$ at each period and wave type by minimizing the following misfit function:

$$
(d-G m)^{T}(d-G m)+a \iint|\nabla m(\mathbf{x})|^{2} \mathrm{~d} x=\min ,
$$

where:

$$
\begin{aligned}
& m(\mathbf{x})=\left(U^{-1}(\mathbf{x})-U_{0}^{-1}\right) U_{0}, \\
& d_{i}=t_{i}-t_{i 0} \\
& (G m)_{i}=\iint G_{i}(\mathbf{x}) m(\mathbf{x}) \mathrm{d} x=\int_{l_{0 i}} m(\mathbf{x}) \frac{\mathrm{d} s}{U_{0}} \\
& \iint G_{i}(\mathbf{x}) \mathrm{d} x=\int_{l_{o i}} \frac{\mathrm{d} s}{U_{0}}=t_{i 0}
\end{aligned}
$$


In relations $(1-5), x=x(\theta, \phi)$ is the position vector, $U_{0}$ is the velocity corresponding to a starting model, $t_{i}$ is the observed travel time along the $i$ th path, $t_{0 i}$ is the travel time calculated for the starting model, $a$ is a regularization parameter, $l_{0 i}$ is the length of the $i$ th path and $s$ is the segment along which the inversion is performed. Parameter $a$ controls the trade-off between the fit to the data and the smoothness of the resulting group velocity maps.

The solution to the seismic tomography problem is non-unique because the initial data do not constrain the seismic velocities at all points of a medium. The knowledge of the resolving power of the data, therefore, allows one to estimate the minimum resolvable inhomogeneity size from the given data sample and to decide, whether or not, features of the solution could possibly be artifacts due to the specific solution method.

The method used in this work to estimate the resolving power of the data in the $2 \mathrm{D}$ problem (Yanovskaya, 1997) generalizes the method proposed by Backus and Gilbert (1968) for the "averaging length" in 1D problems. For 2D tomography problems (Yanovskaya et al., 1998), a functional $s(x, y)$ for different orientations of the coordinate system is used in order to determine the sizes of the averaging area along different directions. The "averaging area" which gives us an idea of the obtained resolution can be approximated by an ellipse centered at a point, with axes equal to the largest $s_{\max }(x, y)$ and to the smallest $s_{\min }(x, y)$ values of $s(x, y)$. The smallest $s_{\min }(x, y)$ and largest $s_{\max }(x, y)$ axes of the ellipse are calculated, and the resolution in each point is given by a single number, which is the mean size of the averaging area $L=\left(s_{\min }(x, y)+s_{\max }(x, y)\right) / 2$. The stretching of the averaging area is given by the ratio $2\left(s_{\max }(x, y)-s_{\min }(x, y)\right) /$ $\left(s_{\max }(x, y)+s_{\min }(x, y)\right)$. Small values of the 'stretching' parameter imply that the paths are more or less, uniformly distributed along all directions, hence the resolution at each point can be represented by the mean size of the averaging area. On the contrary, large values of this parameter (usually $>1$ ) mean that the paths have a preferred orientation, and that the resolution along this direction is likely to be quite small (Yanovskaya, 1997).

Another criterion on the quality of the solution is the comparison of the initial mean square travel time residual and the remaining (unaccounted) residual $\sigma$.
As it has been assumed that the unaccounted residuals are random, $\sigma$ can be accepted as an estimate of the standard error of the data, which allows a standard error of the solution $\sigma_{\mathrm{m}}$ to be computed. The value of $\sigma$ is also used in this study for the selection of the appropriate data: if for one path the travel time residual is larger than $3 \sigma$, the corresponding path is eliminated from the data set and the solution is recalculated (Yanovskaya et al., 1998). The final result of the tomographic inversion is the spatial group velocity distribution, the locally averaged dispersion curves and the corresponding standard errors of the group velocities at discrete points of the area under study.

\section{Group velocity maps}

Using the tomographic method as described in the previous section, Rayleigh waves group velocity maps at $6,10,14,19,24$ and $28 \mathrm{~s}$ have been produced (Fig. $5)$. The maps represent variations from the average group velocity across the studied area. Calculations of group velocity maps were made for several regularization parameters, $\alpha=0.02, \alpha=0.1, \alpha=0.2$. Decrease in $\alpha$ gives a sharper solution region with an increase in solution error, whereas increase in $\alpha$ leads to smoothing of the solution region with decrease in solution error. Finally, we preferred to use the value of $\alpha=0.2$, which gives relatively smooth maps with small solution errors.

For different periods, the number of data before and after the selection, and the initial and remaining mean square travel time residuals are listed in Table 2. We calculated the a priori error in the data set for different periods, in order to compare it with the remaining residual, by the following procedure: We consider a normal grid, using a step of $0.1^{\circ}$, which was superimposed on the study area. For each station and node of the grid, we select the earthquakes recorded at this station with their epicenters not varying from the node by more than $35 \mathrm{~km}$. These earthquakes are taken as a group, and for each group the mean value and standard error in travel time is calculated. Finally, an average travel-time error is estimated using all the groups corresponding to different stations. In Fig. 6a the a priori error is plotted against the remaining residual for different values of period. It can be observed that for the period range of $8-24 \mathrm{~s}$, the remaining residuals are 


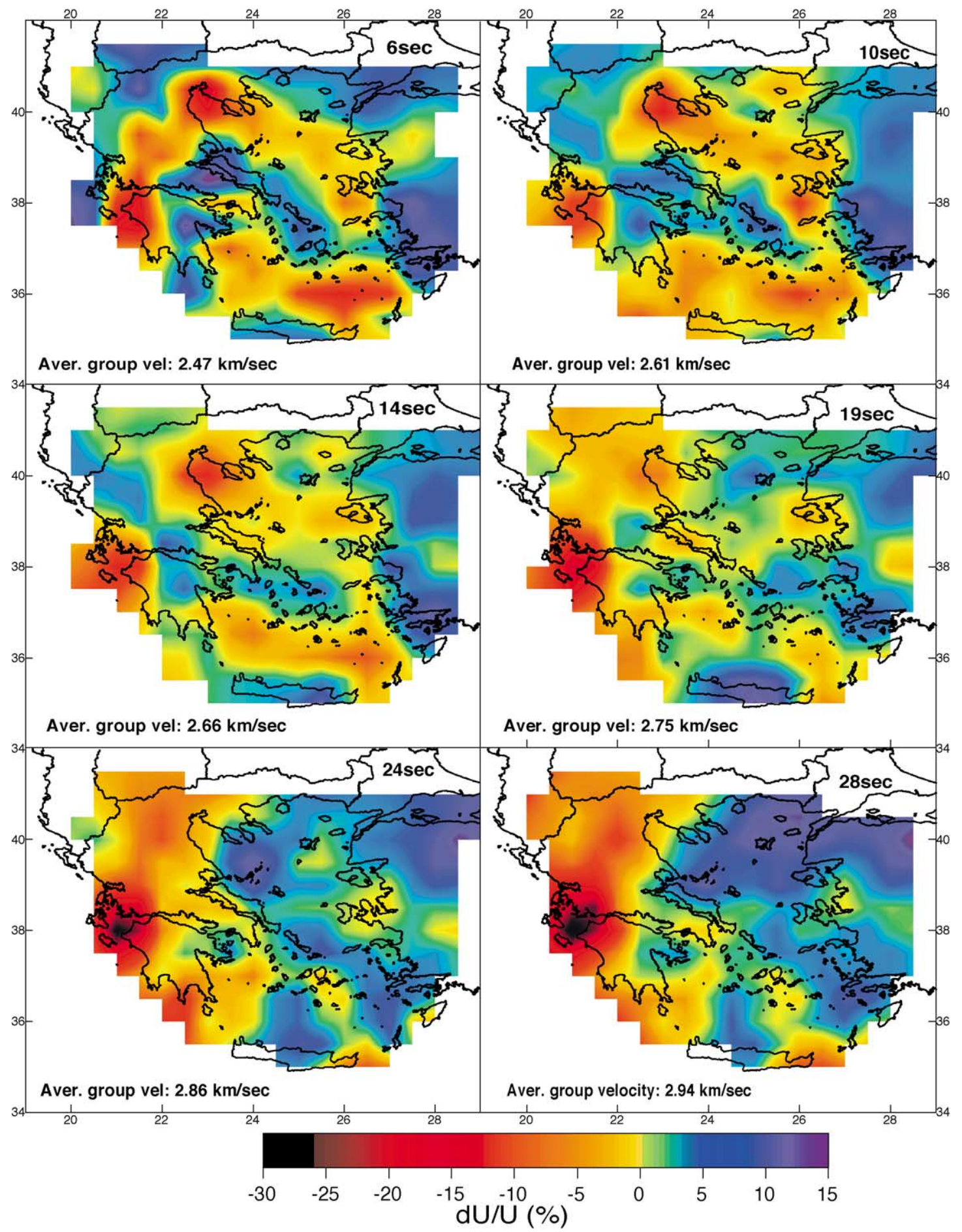

Fig. 5. Estimated Rayleigh wave group velocity maps at the indicated periods. Maps represent lateral variations (in percent) of group velocity relative to the average group velocity across each map. 
Table 2

Number of data and values of the initial (before the tomography) and remaining (after the tomography) group travel-time residuals for different periods

\begin{tabular}{lllll}
\hline $\begin{array}{l}\text { Period } \\
\text { (s) }\end{array}$ & $\begin{array}{l}\text { Number of } \\
\text { initial data }\end{array}$ & $\begin{array}{l}\text { Number of } \\
\text { remaining data }\end{array}$ & $\begin{array}{l}\text { Initial } \\
\text { residual (s) }\end{array}$ & $\begin{array}{l}\text { Remaining } \\
\text { residual (s) }\end{array}$ \\
\hline 6 & 573 & 565 & 15.32 & 7.59 \\
8 & 746 & 716 & 10.48 & 5.77 \\
10 & 779 & 741 & 9.44 & 4.82 \\
12 & 763 & 719 & 9.00 & 4.58 \\
14 & 759 & 720 & 8.92 & 4.86 \\
16 & 720 & 682 & 9.05 & 4.95 \\
19 & 663 & 628 & 9.88 & 5.59 \\
22 & 528 & 510 & 11.34 & 6.90 \\
24 & 487 & 470 & 12.12 & 7.35 \\
26 & 402 & 391 & 12.66 & 7.97 \\
28 & 335 & 326 & 12.85 & 7.87 \\
\hline
\end{tabular}

almost equal to the a priori errors. Therefore we can conclude that the effect of azimuthal anisotropy is negligible for this period interval, and the group velocity maps can give very good results, which interpret the data up to the level of 'noise'. In using the term 'noise' we refer to the measurements errors, the errors due to the mislocations of epicenters and the effect of the source group time shift. For the shortest $(6,8 \mathrm{~s})$ and longest periods $(24,28 \mathrm{~s})$, the difference between the remaining residual and the a priori error is larger, hence the lateral heterogeneities observed at the group velocity maps for these periods can explain only a part of the residuals. As can be seen in Fig. 6b, the difference between the a priori and posteriori error (remaining residual) is controlled partly by the number of paths, where the number of paths is reduced at the border periods.

The standard errors associated with the regionalized group velocities range from 0.04 to $0.09 \mathrm{~km} / \mathrm{s}$ (Fig. 7). The dimensions of the heterogeneities that can be resolved in the various parts of the region under study can be estimated from the resolution maps. The resolution length (the mean size of the averaging area) of our tomographic results is of the order of $50-150 \mathrm{~km}$ in the central part of the maps, but becomes worse near the borders of the region where the path coverage is poor (Fig. 8). The stretching parameter of the averaging area (Fig. 9) has values that are generally smaller than one, indicating that the azimuthal distribution of the paths is approximately uniform and that the resolution is almost the same along any direction. In some areas such as Western Turkey, the good distribution of a small number of crossed ray paths results in a small value of the stretching parameter. The opposite can be observed in areas with good ray coverage, as a relatively large value of the stretching parameter is observed due to the fact that many paths have similar
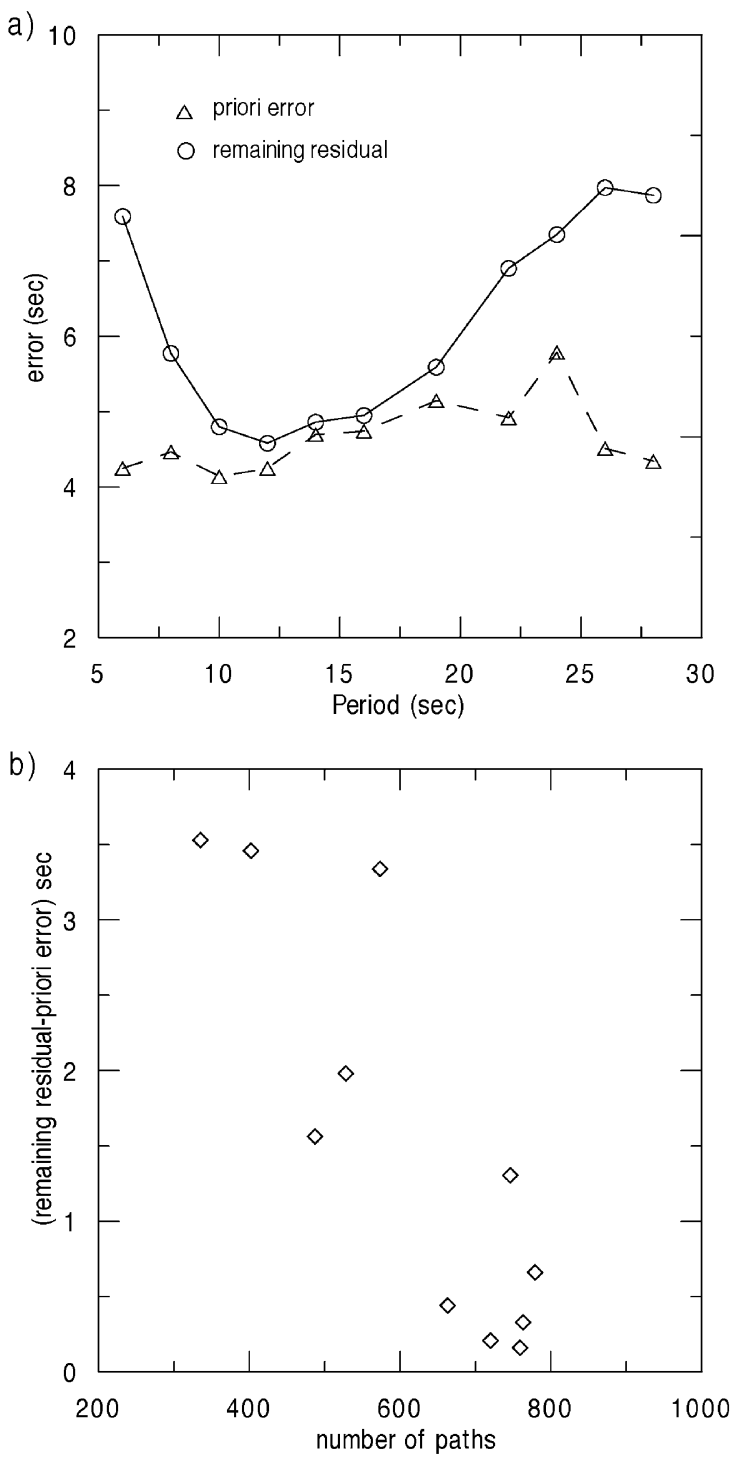

Fig. 6. (a) A priori (estimated independently from the tomography) and a posteriori (after the tomography) error for different periods. Notice the very good agreement for periods between 8 and 24 s. (b) Difference between the a priori and posteriori error as a function of the number of paths. 


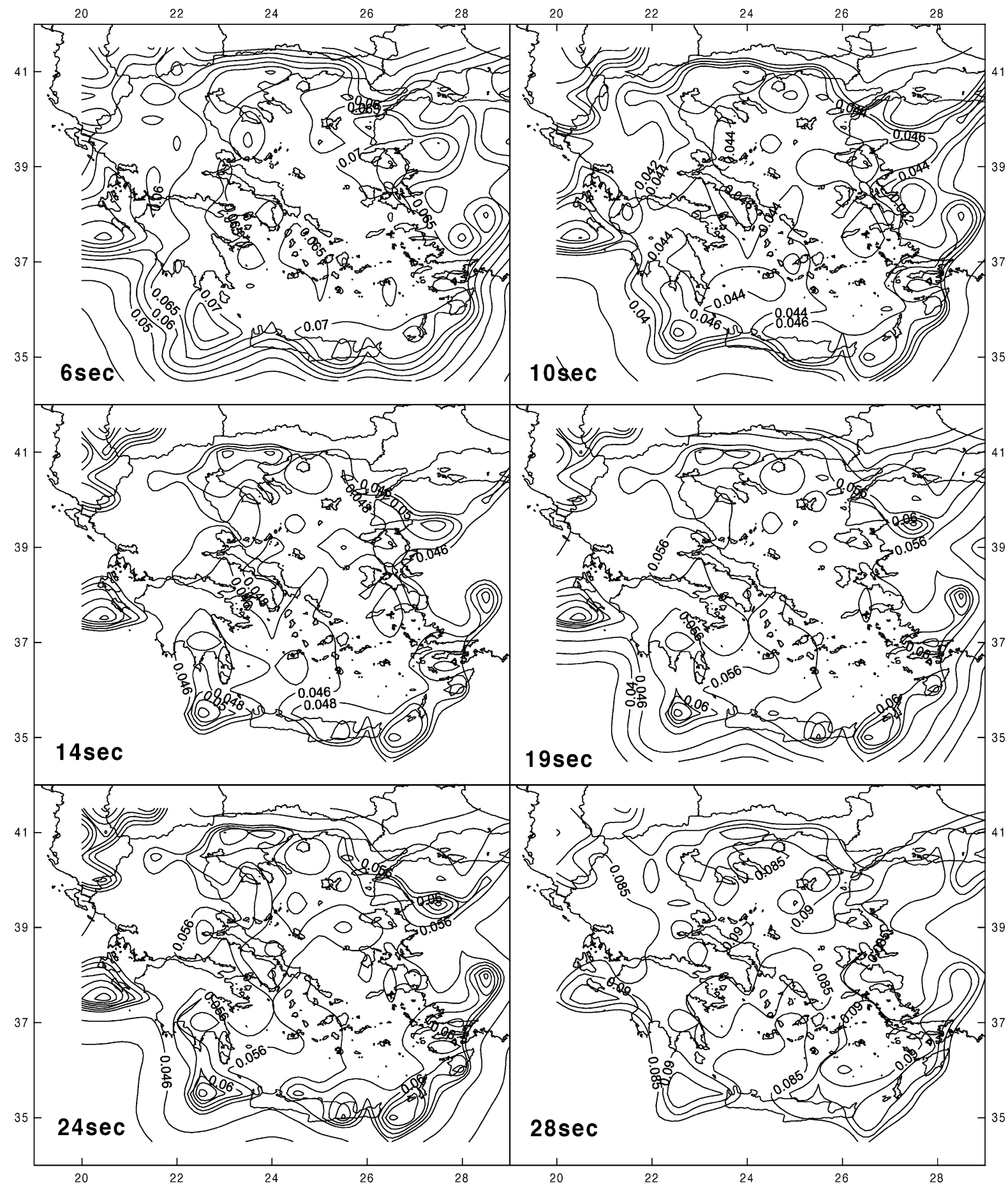

Fig. 7. Standard errors (in km/s) associated with the estimated group velocity maps (same periods as in Fig. 5). 


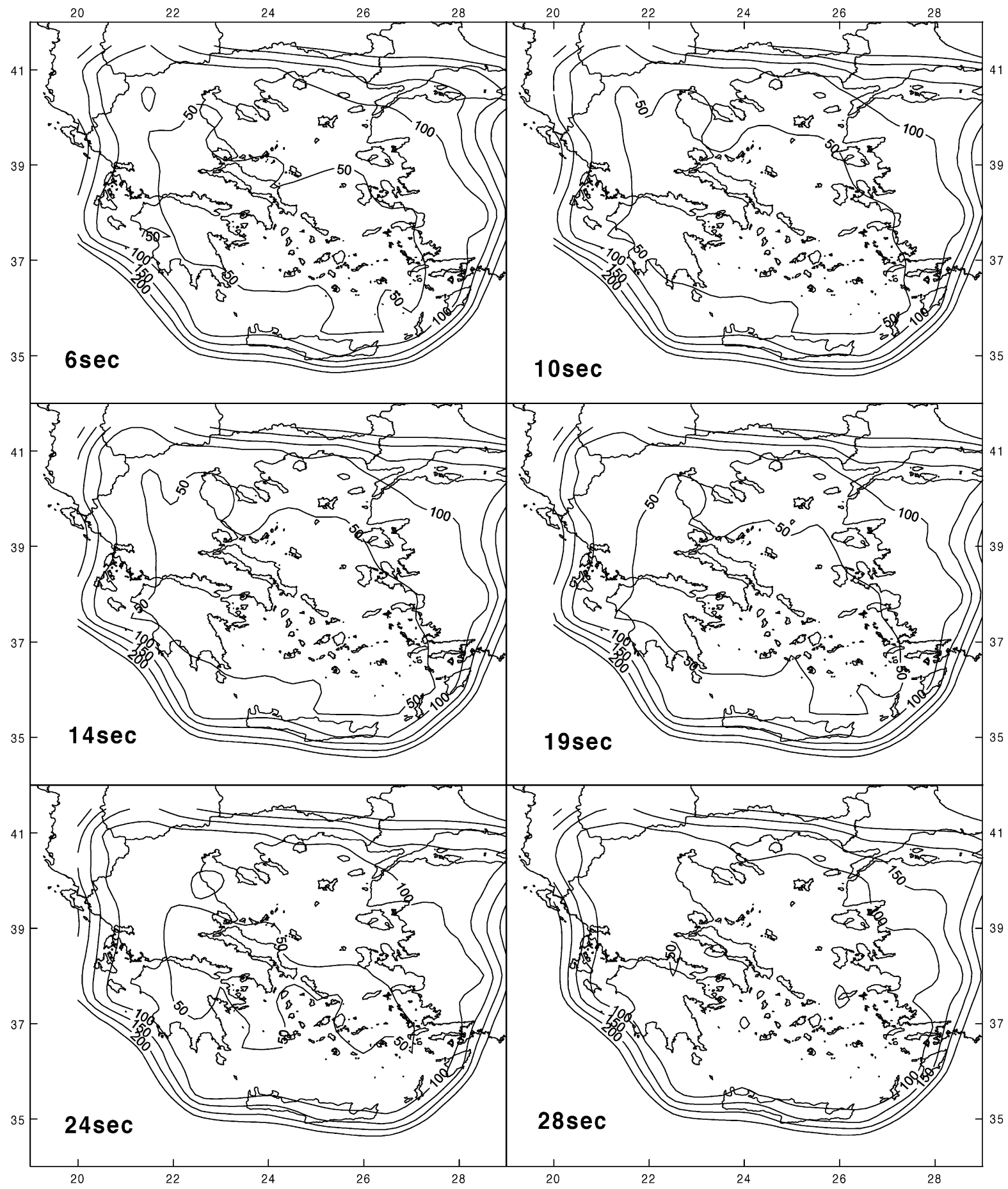

Fig. 8. Resolution length (in $\mathrm{km}$ ) for the studied area (same periods as in Fig. 5). 


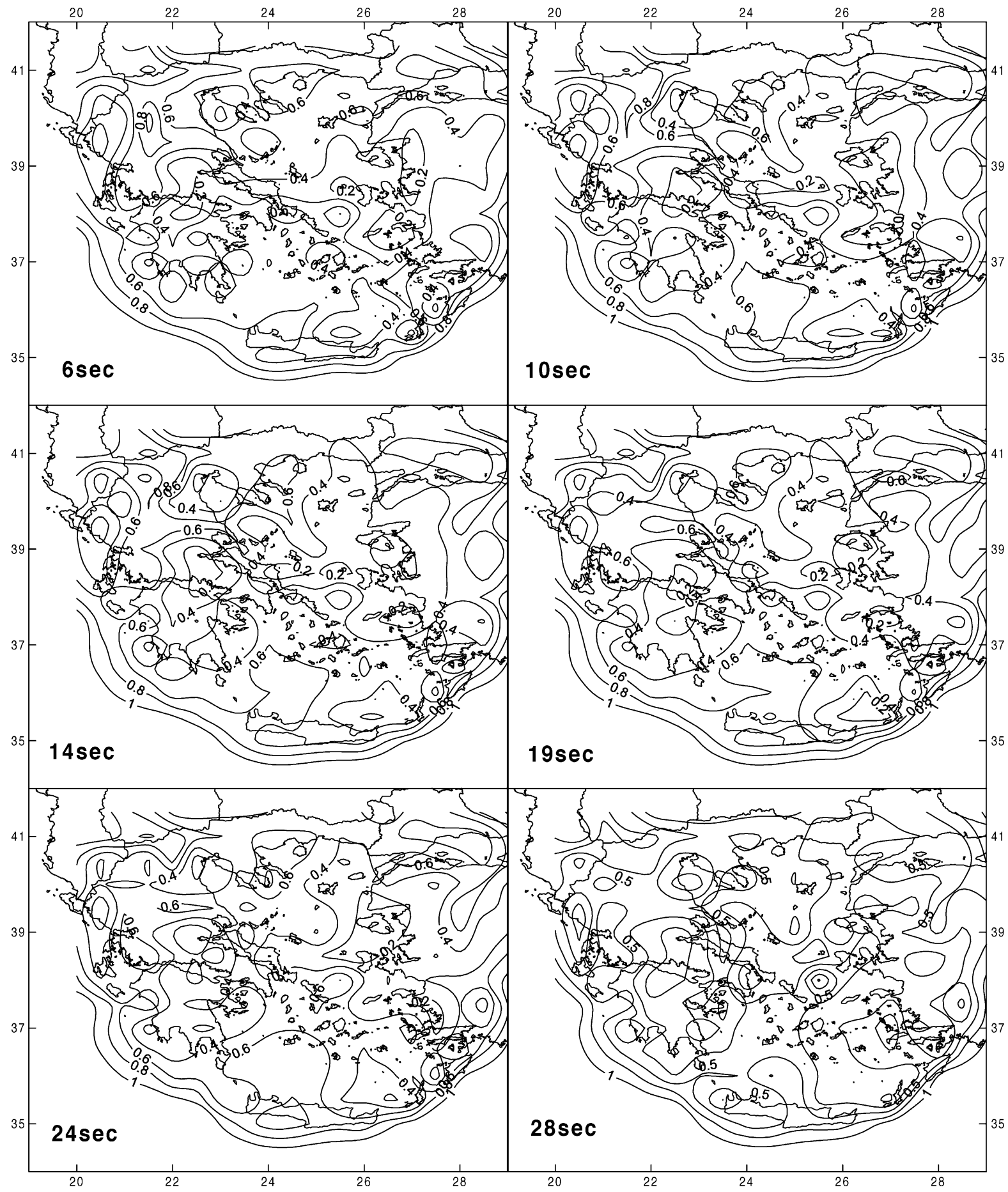

Fig. 9. Distribution of the elongation of the averaging area for the studied region (same periods as in Fig. 5). 
directions. This is confirmed in Fig. 8, where the large values of the resolution length are associated with a small number of the crossed paths in Western Turkey, whereas in the Central Aegean area where the resolution length is sufficiently small (large number of paths) the stretching parameter is higher. In Fig. 5 we present the results only for the area where the resolution length is less than $200 \mathrm{~km}$.

The velocity anomalies at short periods of 6,10 and $14 \mathrm{~s}$ are mostly correlated with shallow geological features (Fig. 1). The low-velocity anomaly observed in Western Greece can be associated with a large thickness of sediments in the Hellenides mountain range, with an average thickness of $4 \mathrm{~km}$ (Panagiotopoulos, 1984), which locally exceeds $10 \mathrm{~km}$ (Makris, 1977, 1978). Another low-velocity anomaly observed in Northern Greece can be attributed to the sedimentary basin of Axios, and to the North Aegean trough. This anomaly continues into the North Aegean Sea towards the islands of Lemnos and Lesvos, its direc-
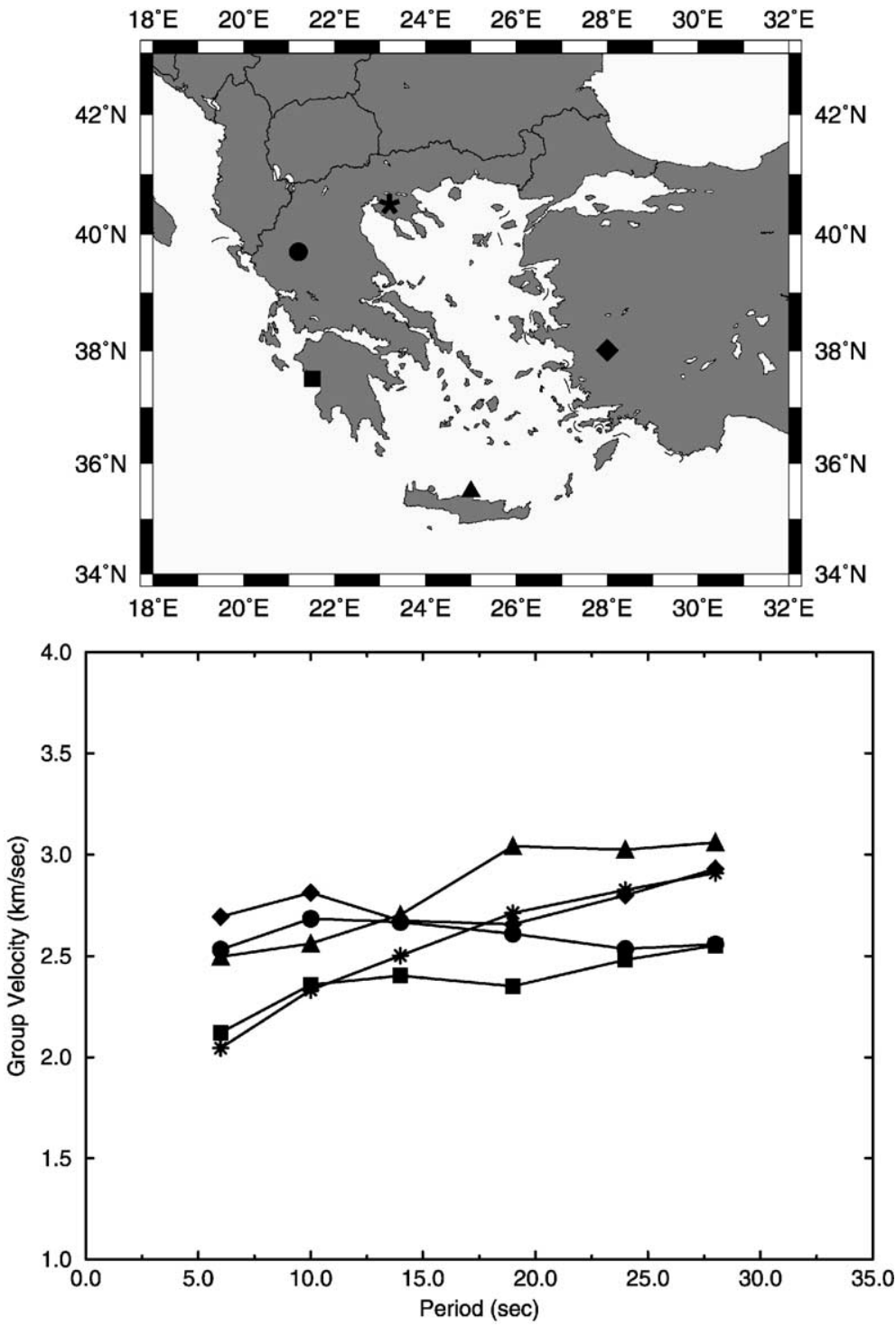

Fig. 10. Local dispersion curves for five different grid points in the studied area, as they are derived from the tomographic maps. 
tion being in good agreement with the direction of geological zones in Northern Greece (Aubouin et al., 1963; Jacobshagen et al., 1978; Mountrakis et al., 1983). The low-velocity anomaly, in the Southern Aegean Sea along the volcanic arc, can be related to the Southern Aegean basin, where high heat flow has been measured and partial melt presence at a depth of about $60 \mathrm{~km}$, as well as nearer the surface, due to the active volcanism, is expected as verified by the active volcanism and tomographic results (e.g. Spakman, 1986; Papazachos and Nolet, 1997).

For periods of $19 \mathrm{~s}$ and larger the situation is different: high-velocity anomalies are observed in the Aegean Sea. In the group velocity map for $24 \mathrm{~s}$ (Fig. 5 ), the velocity anomalies are mostly produced by the lower crust-uppermost mantle structure. The highvelocity anomalies in the inner Aegean Sea can be related to the thin crust (around $20-30 \mathrm{~km}$ ), in contrast to the low-velocity anomaly observed in Western Greece where the crust has a thickness of the order of $42 \mathrm{~km}$, and exceeds $46 \mathrm{~km}$ below Peloponnesos, so that the velocity anomalies are still affected by the crust structure (e.g. Makris, 1975, 1978; Papazachos, 1994). Finally, at the period of $28 \mathrm{~s}$ the high velocityanomalies dominate in the inner Aegean Sea. This is particularly true for the North Aegean Sea, where previous investigations suggest that the crust is relatively thin; about $25 \mathrm{~km}$ (Brooks and Kiriakidis, 1986) and $P_{\mathrm{n}}-S_{\mathrm{n}}$ velocities are high (Papazachos and Nolet, 1997). Therefore, in the North Aegean Sea the transition zone between the lower crust and the upper mantle can be well resolved.

Using the group velocity maps of Rayleigh waves at different periods as derived from tomography, a local group velocity curve was constructed for each cell $\left(0.5^{0} \times 0.5^{0}\right)$ of the gridded area under study. In Fig. 10, the local dispersion curves for five different cells are shown. For periods smaller than $15 \mathrm{~s}$, low values of group velocities (around $2.5 \mathrm{~km} / \mathrm{s}$ ) are presented for these five cells. The lowest group velocities are obtained for the cell at the Peloponessos and in Northern Greece, and are related to the big thickness of sediments. For the periods of $20 \mathrm{~s}$ and more, the values of the local group velocities are higher. At $28 \mathrm{~s}$ the highest value is obtained in the Cretan Sea, whereas the smallest is in Peloponessos, as one would expect, since the crust is thin in the Cretan Sea region and thick under Peloponnesos.

\section{Inversion}

The local averaged dispersion curves of the fundamental mode of Rayleigh waves for the two cells shown in Figs. 12 and 13 were inverted to obtain Swave velocity versus depth models. The method of inversion used here is known as the Hedgehog method (Keilis-Borok and Yanovskaya, 1967; Press, 1968, 1969; Knopoff, 1972; Biswas and Knopoff, 1974; Calcagnile and Panza, 1980; Panza 1980). The Earth model is parameterized by density and P- and S-wave velocities, as a function of depth. The parameters may be varied or held fixed in the inversion and be independent or dependent, based on the a priori knowledge. For the independent parameters acceptable models are sought, whereas the dependent parameters maintain a fixed relationship with the independent ones. Since the partial derivatives of phase and group velocity with respect to the shear-wave velocity are larger than those with respect to the compressional wave velocity and density (Du et al., 1998), only the Swave velocity and the layer thicknesses have been defined as independent parameters. Each parameter to be inverted is specified to lie within a particular range with upper and lower bounds. Theoretical dispersion curves are computed using the Knopoff method (Knopoff, 1964; Schwab and Knopoff, 1972). Starting from the largest period, the theoretical group velocity is computed and compared with the observed value. If the difference lies within a limit consistent with observational errors (usually less than $0.08 \mathrm{~km} / \mathrm{s}$ ), the program proceeds to test the next shorter period and so on. If this test fails at any individual period, the model is rejected and a new model in the neighborhood of the previous one is tested. If the test is successful at all individual periods, the RMS difference between theoretical and observed values is computed and compared with a preset value, usually less than $0.06 \mathrm{~km} / \mathrm{s}$. A model that passes both criteria is acceptable, and the same process is repeated until the neighborhood around each satisfactory combination of the searching parameters is explored.

Using the Hedgehog inversion, the local dispersion curves of Rayleigh waves for two discrete cells in the region under study (average dispersion curve using the local dispersion curves at every knot of each cell) were inverted to obtain vertical models of S-wave velocity. Because group velocity data are available only in the 
range of 5-30 s, in general it is only possible to resolve the parameters of the upper and lower crust, but in other cases where there is a relatively thin crust, the transition zone between the crust and upper mantle can also be resolved.

As a priori information we have taken the models of S-waves as deduced from the work of Papazachos and Nolet (1997). The starting stratified structure is overlain by a water layer of variable thickness $(0.2-2.5$ $\mathrm{km}$ ), according to the bathymetric map for the Mediterranean area. The elastic properties for the upper 3-5 $\mathrm{km}$ were fixed by considering the seismic soundings performed by the Company of Greek petroleum (personal communication), and other geophysical data (Roussos, 1994; Makris, 1976, 1977; Martin, 1987). The density in all layers and mantle parameters were held fixed based on the same results of Papazachos and Nolet (1997). The P-wave velocities were defined, as dependent on the values of S-wave velocities, and the $V_{\mathrm{P}} / V_{\mathrm{S}}$ ratio was set equal to 1.78 for the two examined cells (Papazachos and Nolet, 1997). Small modifications in the upper 3-4 $\mathrm{km}$ do not have a critical influence on the results of our inversion, since we have limited the shorter period of our group velocity data at $6 \mathrm{~s}$. We performed several tests where the $\mathrm{S}$ wave velocities at the shallow layers were modified up to $0.5 \mathrm{~km} / \mathrm{s}$, and the thickness of the shallow layers was modified up to $0.5-1 \mathrm{~km}$. All the tests showed that for the inversion results the imposed variations of the $\mathrm{S}$ wave velocities were of the order of $0.02-0.09 \mathrm{~km} / \mathrm{s}$, while the depth of Moho varied by $1 \mathrm{~km}$.

Eight to ten parameters were allowed to vary in the inversion scheme, namely the velocities in four to five layers reaching a depth of about $40-45 \mathrm{~km}$, and the thickness of four to five of these layers. The steps for the velocity parameters were estimated according to the resolving power of the information contained in the available data (Panza, 1980).

For the two cells under consideration, the shearwave velocity models versus depth resulting from the inversion are presented in Figs. 12 and 13. In these figures, the shadowed region corresponds to the search area, where the inversion is performed, with the thin lines showing all the possible solutions determined from the inversion. The thick lines represent the solution having the smallest RMS, and the dotted lines present the "average" solution with its standard deviation. In both figures, the location of the cell is shown, as well as the observed local group velocity curve with its standard deviation, and the theoretical group velocity curve corresponding to the solution of the inversion with the smallest rms.

The partial derivative of the group velocity with respect to $\mathrm{S}$ wave velocity, $\mathrm{d} U(T) / \mathrm{d} \beta$, shows the largest values at a depth of about $h=0.4 \lambda_{\mathrm{R}}$, where $\lambda_{\mathrm{R}}$ is the wavelength of the Rayleigh wave (Knopoff, 1972), suggesting that the $\mathrm{S}$ wave velocity at the depth, $h$, has the greatest influence on the group velocity curve, $U(T)$, at periods near $T$. In Fig. 11 we have plotted the quantity $\mathrm{d} U(T) / \mathrm{d} \beta$, which reflects the sensitivity of the group velocity on the shear wave velocity versus depth for the two examined cells at the Northern (Fig. 11a) and Southern Aegean Sea (Fig. 11b) for the periods of 6,20 and $28 \mathrm{~s}$. At $6 \mathrm{~s}$, the shortest period of our experimental data, $\mathrm{d} U(T) / \mathrm{d} \beta$ shows a peak at a depth of about $10 \mathrm{~km}$, for both models at the Northern and Southern Aegean Sea. Group velocity at $6 \mathrm{~s}$ is sensitive to variations of the $\mathrm{S}$ wave velocity at depths smaller than $10 \mathrm{~km}$ (absolute sensitivity $>0.5$ ). This means that from the Rayleigh wave at $6 \mathrm{~s}$, we can obtain reliable information about $\mathrm{S}$ wave velocities for depths from 3 to $10 \mathrm{~km}$. At $20 \mathrm{~s}, \mathrm{~d} U(T) / \mathrm{d} \beta$ shows a peak at a depth of about $25 \mathrm{~km}$ for the Northern Aegean Sea model and a peak at a depth of about $15 \mathrm{~km}$ for the Southern Aegean Sea model while at $28 \mathrm{~s}$, the corresponding peak values are observed for depths of about 40 and 35 $\mathrm{km}$, respectively. S wave velocities at depths of about $50 \mathrm{~km}$ still have a significant influence on the values of group velocities (absolute sensitivity $\sim 0.6$ ), suggesting that the Rayleigh waves at $28 \mathrm{~s}$ are still sensitive to the uppermost mantle structure.

The solutions of the inversion for the cell in the Northern Aegean Sea are presented in Fig. 12a. Since the solutions presented in Fig. 12a have significant overlapping and are difficult to discern, we have also computed and shown the 'average' solution which is represented by possible velocity intervals at several depths. There are 42 solutions of the Hedgehog inversion for this case. Although the solutions seem to have a large scatter, the average solution exhibits low up to intermediate standard deviation values $(0.02-0.3 \mathrm{~km} /$ $\mathrm{s})$, suggesting that most of the solutions do not have very large differences. In particular, for depths between 4 and $16 \mathrm{~km}$ all the solutions of the inversion exhibit an S wave velocity of about $3.4 \mathrm{~km} / \mathrm{s}$. The $\mathrm{S}$ wave velocity increases with depth, and in the depth 
Vs sensitivity
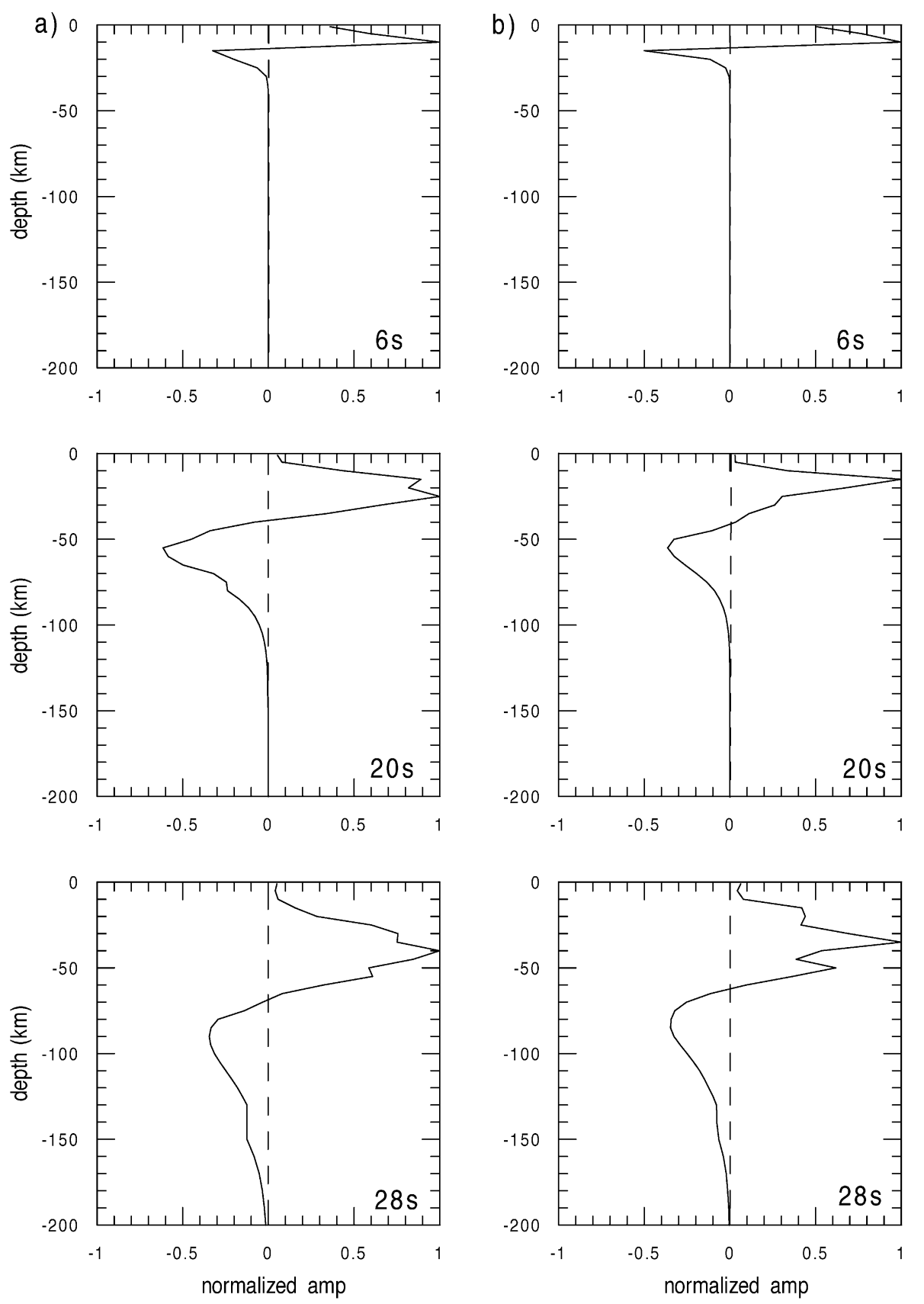

Fig. 11. Rayleigh wave group velocity sensitivity kernels with respect to shear velocity for the periods of 6,20 and $28 \mathrm{~s}$ computed for the Hedgehog solutions having the smallest rms value. (a) For the point in the Northern Aegean Sea and (b) for the point in the Southern Aegean Sea. 


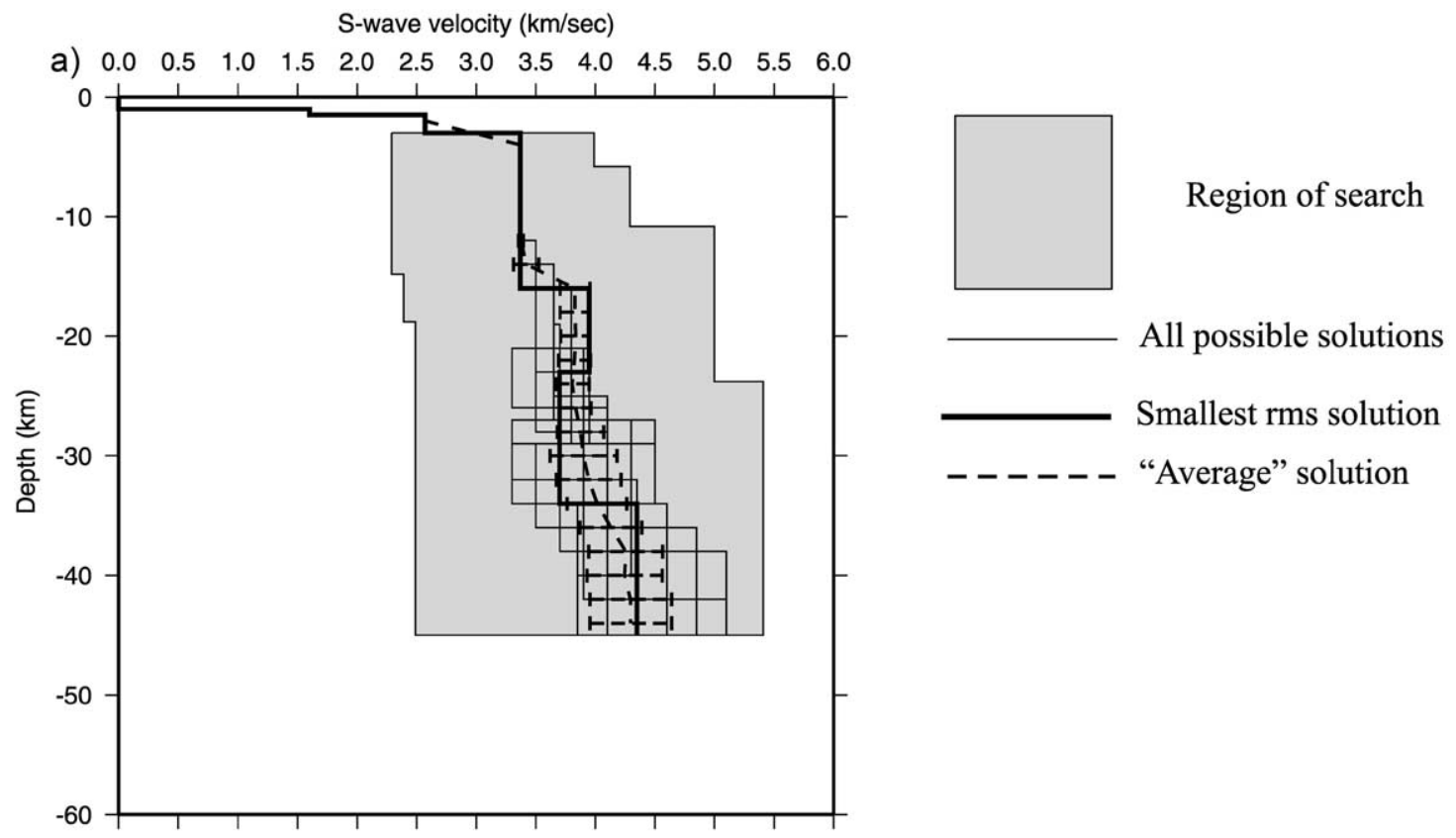

b)

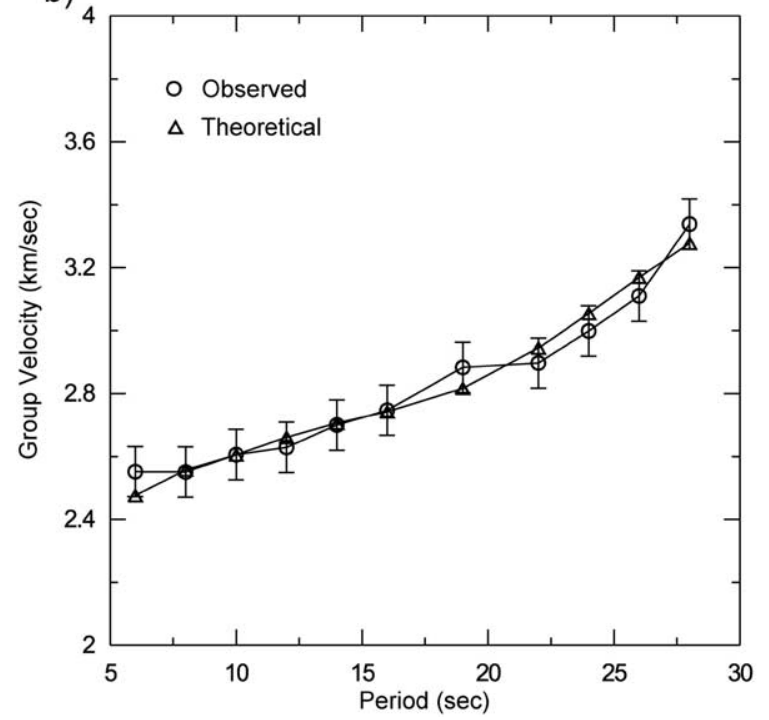

C)

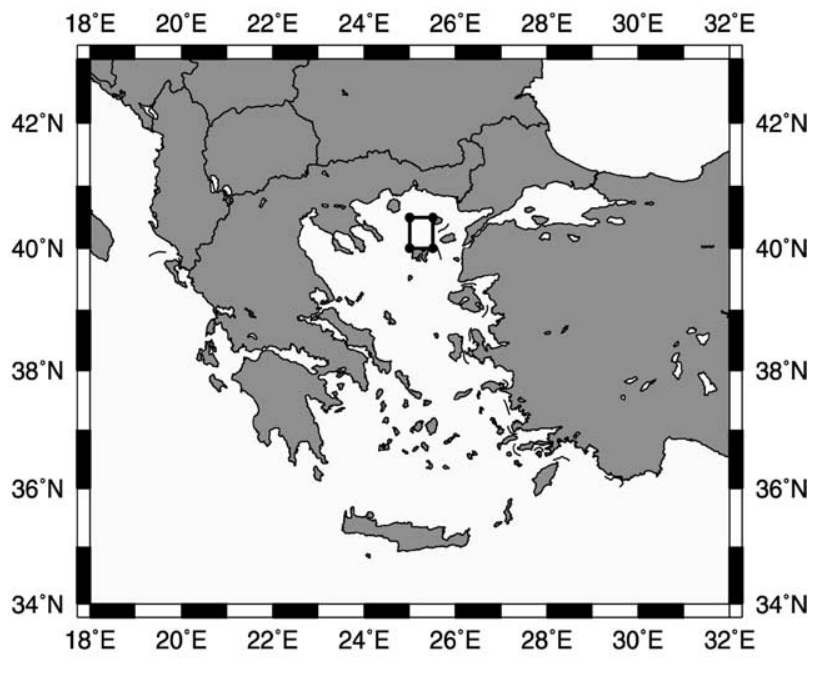

Fig. 12. (a) Shear-wave velocity models corresponding to the average group velocity curve at the center of the cell $\left(0.5^{0} \times 0.5^{0}\right)$ at Northern Aegean Sea. The shadowed region corresponds to the area where the inversion search is performed, with the thin lines denoting all the possible solutions of the inversion. The thick line represents the solution having the smallest rms, and the dotted line shows the "average" solution with its standard deviation. (b) The misfit between the observed local group velocity curve and the theoretical dispersion curve corresponding to the solution of the inversion with the smallest rms. (c) The cell for the area under study where the inversion has been performed.

range of $16-26 \mathrm{~km}$ the average solution shows a mean value of an $\mathrm{S}$ wave velocity around $3.8 \mathrm{~km} / \mathrm{s}$, with a standard deviation around $0.13 \mathrm{~km} / \mathrm{s}$. For the same depth range, there are only three solutions $(\sim 7 \%)$ with $\mathrm{S}$ wave velocities around $3.4 \mathrm{~km} / \mathrm{s}$, and most of the solutions $(\sim 81 \%)$ concentrate around the average 
velocity. In the depth range of $25-30 \mathrm{~km}$, we can observe that the $\mathrm{S}$ wave velocity of the average solution is around $3.9 \mathrm{~km} / \mathrm{s}$ with a standard deviation of about $0.2 \mathrm{~km} / \mathrm{s}$. Few solutions with lower $(\sim 3.4$ $\mathrm{km} / \mathrm{s}, 9 \%)$ or higher $\mathrm{S}$ wave velocities $(\sim 4.5 \mathrm{~km} / \mathrm{s}$,
5\%) are observed. At greater depths $(>30 \mathrm{~km})$, the average S wave velocity is approximately $4.25 \mathrm{~km} / \mathrm{s}$, and the standard deviation is of the order of $0.25-0.35$ $\mathrm{km} / \mathrm{s}$. Thirty-seven solutions $(90 \%)$ show $\mathrm{S}$ wave velocities ranging from 3.9 to $4.6 \mathrm{~km} / \mathrm{s}$ and only five

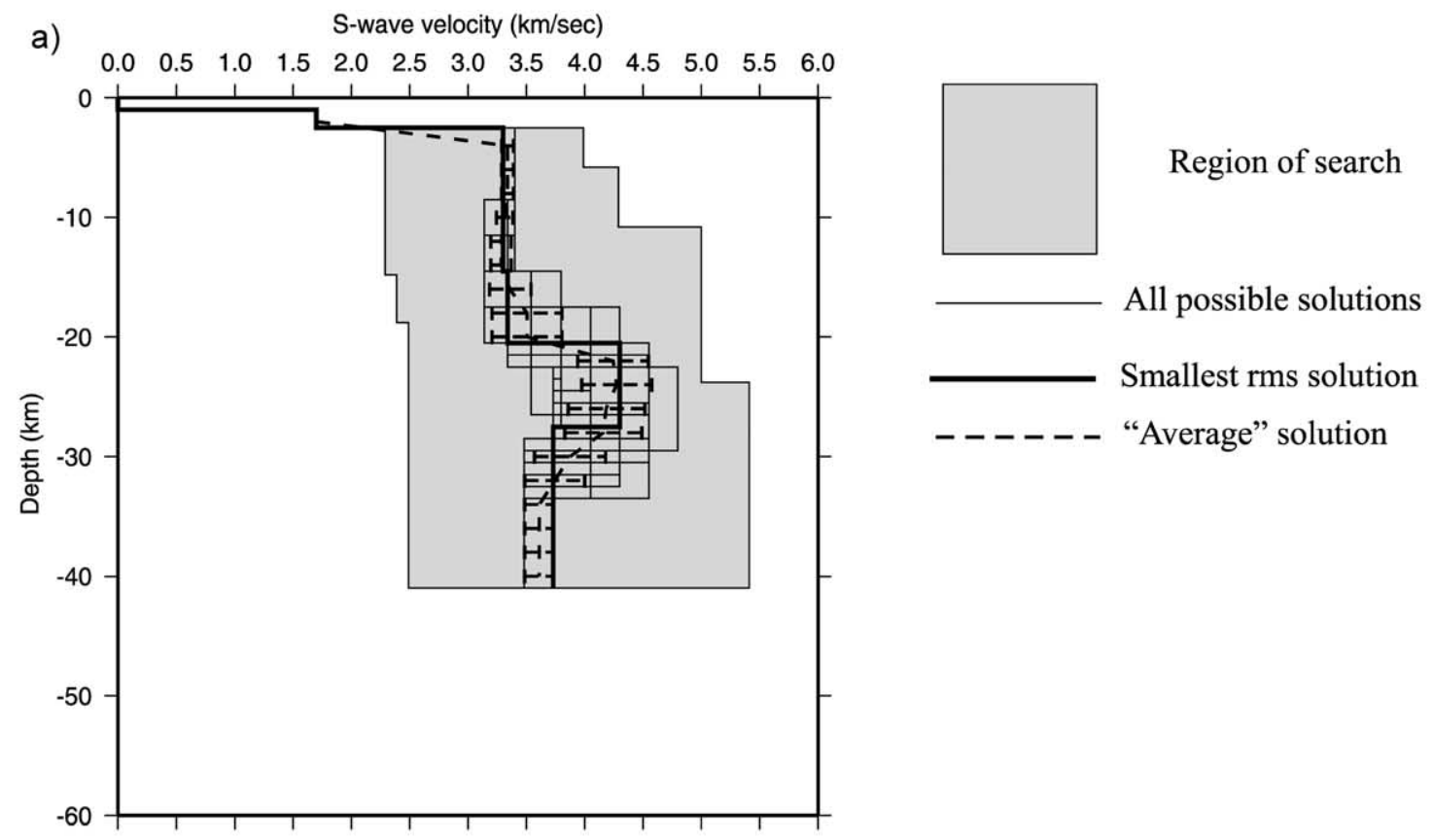

b)

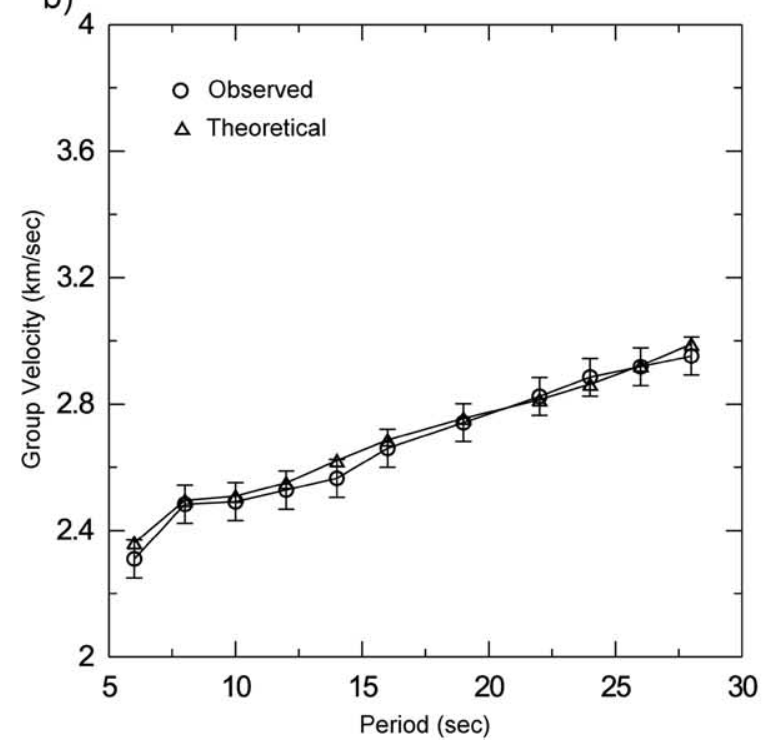

c)

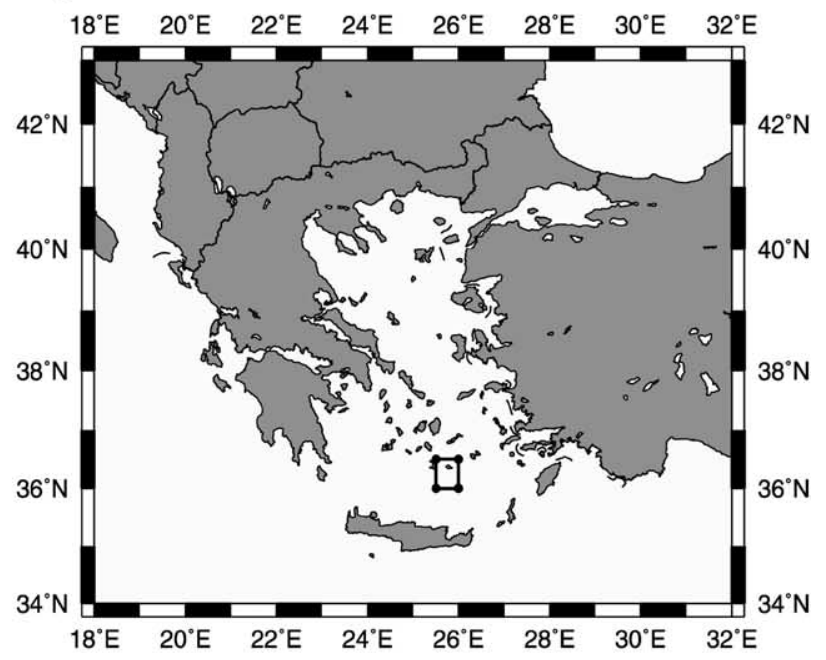

Fig. 13. Shear-wave velocity models corresponding to the average group velocity curve at the center of the cell $\left(0.5^{0} \times 0.5^{0}\right)$ at Southern Aegean Sea (same as in Fig. 12). 
solutions $(10 \%)$ show higher $\mathrm{S}$ wave velocities (4.8$5.0 \mathrm{~km} / \mathrm{s}$ ) at depths of about $38-42 \mathrm{~km}$. In conclusion, the inversion results for the Northern Aegean cell supply a lower limit of about $27 \mathrm{~km}$ and an upper limit of about $37 \mathrm{~km}$ for the crustal thickness, with the $\mathrm{S}$ wave velocities for the upper mantle varying from 4.1 to $4.8 \mathrm{~km} / \mathrm{s}$. Our results are consistent with the work of Papazachos and Nolet (1997), which suggests a crustal thickness of about $30 \mathrm{~km}$ for the broader area of the examined cell.

The Hedgehog inversion scheme found 27 solutions able to fit the observations for the Southern Aegean Sea cell close to Santorini Island (Fig. 13). At depths up to $20 \mathrm{~km}$ and greater than $30 \mathrm{~km}$, the standard deviation of the average solution is less than $0.25 \mathrm{~km} / \mathrm{s}$. At smaller depths $(<14 \mathrm{~km})$ the average solution shows an $\mathrm{S}$ wave velocity of about $3.3 \mathrm{~km} / \mathrm{s}$ with a standard deviation of about $0.08 \mathrm{~km} / \mathrm{s}$. At intermediate depths $(15-20 \mathrm{~km})$, few solutions $(15 \%)$ exhibit $\mathrm{S}$ wave velocities ranging from 3.8 to $4.3 \mathrm{~km} / \mathrm{s}$. Eighty-five percent of the solutions are mostly concentrated around the average solution which has an $\mathrm{S}$ wave velocity of about $3.5 \mathrm{~km} / \mathrm{s}$. Some of the solutions $(36 \%)$ show a low-velocity layer at a depth between 10 and $20 \mathrm{~km}$, which might be interpreted as a signature of granitic intrusions (Mueller, 1977). In the depth range of $20-26 \mathrm{~km}$, the average solution shows an $\mathrm{S}$ wave velocity close to $4.3 \mathrm{~km} / \mathrm{s}$, and a standard deviation of about $0.30 \mathrm{~km} / \mathrm{s}$. S wave velocities in this depth range show values between 4.0 and $4.6 \mathrm{~km} / \mathrm{s}(84 \%)$, which could be interpreted as typical of the uppermost mantle. These high $\mathrm{S}$ wave velocities are found up to a depth of about $30 \mathrm{~km}$, while at greater depths $(<40 \mathrm{~km})$ the average $\mathrm{S}$ wave velocities decrease to $3.6-3.8 \mathrm{~km} / \mathrm{s}$, with a standard deviation of about $0.12-0.25 \mathrm{~km} / \mathrm{s}$. Low $\mathrm{S}$ wave velocities found in the upper mantle can be correlated with the presence of partial melt at these depths, responsible for the observed high heat flow and active volcanism (e.g. Spakman, 1986; Fytikas et al., 1989; Papazachos and Nolet, 1997).

\section{Discussion-conclusions}

We have presented the results of a study of the Rayleigh wave dispersion for the period range of 5$30 \mathrm{~s}$ across the Aegean area. The broad-band seis- mometers with high-quality digital seismic stations from three temporary networks installed in the broader Aegean area have given the opportunity to present high resolution maps of lateral group velocity variations of the area, with the use of the records of Rayleigh waves in order to determine a shear velocity structure for discrete points of the area under study.

The results of surface wave tomography exhibit clear strong lateral variations in the Aegean area that can often be correlated with regional tectonics. Significant lateral heterogeneity can be identified for different depths up to $30-45 \mathrm{~km}$, considering that the group velocity maps have been calculated for a large range of periods between 5 and $30 \mathrm{~s}$. The big thickness of sediments in Western Greece under the Hellenides mountain range, the sedimentary basin of Axios in Northern Greece continuing to the Northern Aegean trough and the Southern Aegean basin, where high heat flow has been measured, are pointed out at the shortest periods (6-14 s). For the period of $19 \mathrm{~s}$, a high-velocity anomaly is observed in Southern Aegean Sea indicating that the crust is relatively thin there, which is in agreement with previous works where a maximum thinning is observed at the Southern Cretan Sea with a crust thickness of around $20 \mathrm{~km}$ (e.g. Makris, 1977). From the period of 24 s, high-velocity anomalies are observed in the inner Aegean Sea connected with the thin crust, whereas low group velocities are still observed in Western Greece due to the thick crust.

The non-linear inversion, as it was applied to selected local dispersion curves, shows that in the North-East Aegean Sea the crust has a total thickness of the order of $32 \mathrm{~km}$ with a mean value of $\mathrm{S}$ wave velocity for the upper mantle of around 4.25 $\mathrm{km} / \mathrm{s}$. In the Southern Aegean Sea we observe a thin crust of around $22-24 \mathrm{~km}$ with a mean value of S wave velocity for the upper mantle of around $4.3 \mathrm{~km} /$ s. A low-velocity layer is observed between 30 and $40 \mathrm{~km}$ with an S wave velocity between 3.6 and 3.8 $\mathrm{km} / \mathrm{s}$ and can be correlated with the high heat flow in this area (Fytikas et al., 1989). This low-velocity zone is in agreement with the work of Kalogeras and Burton (1996) who showed a low-velocity zone centered at a depth of about $30 \mathrm{~km}$ for three paths from Carpathos, Rhodes and South-West Turkey to Athens. 


\section{Acknowledgements}

The data collection for this work was financed by the E.C. Environment and Climate project (contract ENV4-CT96-0277). Part of this work was done while the first author was an Erasmus-Socrates fellowship student at the University of Trieste, Italy. We are grateful to Prof. Anatoli Levshin for providing the FTAN code, and Prof. T. Yanovskaya and P. Ditmar from the University of St. Petersburg, Russia, for providing the tomographic inversion program. We would also like to thank the Institute des GeoForschungsZentrums, Potsdam, Germany, for providing the records from their network in the South Aegean Sea. Finally, we are grateful to Thanasis Karamesinis, Afroditi Karnassopoulou, Ioannis Kassaras, Georgios Kaviris, Eleni Louvari, Kiriaki Paulou and Kiriakos Peftitselis for their help in the field. We would also like to thank Susan Van der Lee, an anonymous reviewer and Irene Artemieva (Ed.) for their helpful comments and suggestions, which helped to improve the paper. We would also like to thank Prof. Hans Thybo and James Cahalane for their helpful comments concerning the paper. E.E. Karagianni would also like to thank the Greek State Scholarship Foundation (G.S.S.F.) for its financial support through a 1996-1999 S.S.F. scholarship. This work is a Department of Geophysics, University of Thessaloniki contribution number \#565\#.

\section{References}

Aubouin, J., Brunn, J.H., Celet, P., Dercourt, J., Godfriaux, I., Mercier, J., 1963. Esquisse de la géologie de la Gréce. Livre Mém. P. Fallot, Mém. Soc. Géol. Fr., Hors-sér. 2, 583-610.

Backus, G., Gilbert, F., 1968. The resolving power of gross earth data. Geophys. J. R. Astron. Soc. 16, 169-205.

Biswas, N.N., Knopoff, L., 1974. The structure of the upper mantle under the United States from the dispersion of Rayleigh waves. Geophys. J. R. Astron. Soc. 36, 515-539.

Brooks, M., Kiriakidis, L., 1986. Subsidence of the North Aegean trough: an alternative view. J. Geol. Soc. (London) 143, $23-27$.

Calcagnile, G., Panza, G.F., 1980. The main characteristics of the lithosphere-asthenosphere system in Italy and surrounding regions. Pure Appl. Geophys. 119, 865-879.

Calcagnile, G., D’Ingeo, F., Farrugia, P., Panza, G.F., 1982. The lithosphere in the Central-Eastern Mediterranean area. Pure Appl. Geophys. 120, 389-406.

Caputo, M., Panza, G.F., Postpischl, D., 1970. Deep structure of the Mediterranean basin. J. Geophys. Res. 75, 4919-4923.
Chailas, S., Hipkin, R.G., Lagios, E., 1993. Isostatic studies in the Hellenides. 2nd Congress of the Hellenic Geophysical Union, 5-7 May, Florina, Macedonia.

Christodoulou, A., Hatzfeld, D., 1988. Three-dimensional crustal and upper mantle structure beneath Chalkidiki (Northern Greece). Earth Planet. Sci. Lett. 88, 153-168.

Delibasis, N., Makris, J., Drakopoulos, J., 1988. Seismic investigation of the crust and the upper mantle in Western Greece. Ann. Geol. Pays Hell. 33, 69-83.

Ditmar, P.G., Yanovskaya, T.B., 1987. A generalization of the Backus-Gilbert method for estimation of lateral variations of surface wave velocity. Phys. Solid Earth Izvestia Acad. Sci. USSR 23 (6), 470-477.

Drakatos, G., 1989. Seismic tomography—Determination of high and low velocity zones beneath Greece and surrounding regions. $\mathrm{PhD}$ thesis, Univ. of Athens, Athens, Greece, $144 \mathrm{pp}$.

Drakatos, G., Latoussakis, J., Stavrakakis, G., Papanastasiou, D., Drakopoulos, J., 1989. 3-Dimensional velocity structure of the North-Central Greece from inversion of travel times. Paper Presented at the 3rd Congress of the Geological Society of Greece, Geol. Soc. of Greece, Athens.

Du, Z.J., Michelini, A., Panza, G.F., Urban, L., 1998. P-SV multimode summation differential seismograms for layered structures. Geophys. J. Int. 134, 747-756.

Fleischer, U., 1964. Schwerestörungen im ostlichen Mittelmeer: nach Messungen mit einem Askania-Seegravimeter. Dtsch. Hydrogr. Z. 17, 4.

Fytikas, M., Innocentri, F., Manetti, P., Mazzuoli, R., Peccerillo, A., Villari, L., 1985. Tertialy to Quaternary evolution of the volcanism in the Aegean region. In: Dixon, J.E., Roberston, A.H. (Eds.), The Geological Evolution of the Eastern Mediterranean. Soc. Geol. Spec. Publ., vol. 17. London.

Fytikas, M.D., Garnish, J.D., Hutton, V.R.S., Staroste, E., Wohlenberg, J., 1989. An integrated model for the geothermal field of Milos from geophysical experiments. Geothermics 18, $611-621$.

Georgalas, G., 1962. Catalogue of the Active Volcanoes and Solfatara Fields in Greece, Part 12. International Association of Volcanology, Rome.

Hashida, T., Stavrakakis, G., Shimazaki, K., 1988. Three-dimensional seismic attenuation beneath the Aegean region and its tectonic implication. Tectonophysics 145, 43-54.

Hatzfeld, D., Karagianni, E., Kassaras, I., Kiratzi, A., Louvari, E., Lyon-Caen, H., Makropoulos, K., Papadimitriou, P., Bock, G., Priestley, K., 2002. Shear wave anisotropy in the upper mantle beneath the Aegean related to internal deformation. J. Geophys. Res. (submitted for publication).

Jackson, J., 1994. Active tectonics of the Aegean region. Annu. Rev. Earth Planet. Sci. 22, 239-271.

Jacobshagen, V., Durr, S., Kockel, F., Kopp, K.O., Kowalczyk, G., 1978. Structure and geodynamic evolution of the Aegean region. In: Closs, H., Roeder, D., Schmidt, K. (Eds.), Alps, Apennines, Hellenides. Schweizerbart, Stuttgart, pp. 537-564.

Kalogeras, J.S., 1993. A contribution of surface seismic waves in the study of the crust and upper mantle in the area of Greece. $\mathrm{PhD}$ thesis, Univ. of Athens, $186 \mathrm{pp}$.

Kalogeras, J.S., Burton, P.W., 1996. Shear-wave velocity models 
from Rayleigh-wave dispersion in the broader Aegean area. Geophys. J. Int. 125, 679-695.

Keilis-Borok, V.I., Yanovskaya, T.B., 1967. Inverse problems of seismology. Geophys. J. R. Astron. Soc. 13, 223-234.

Knopoff, L., 1964. A matrix method for elastic wave problems. Bull. Seismol. Soc. Am. 54, 431-438.

Knopoff, L., 1972. Observation and inversion of surface wave dispersion. Tectonophysics 13, 497-519.

Le Pichon, X., Angelier, J., 1979. The Hellenic arc and trench system: a key to the neotectonic evolution of the Eastern Mediterranean area. Tectonophysics 60, 1-42.

Levshin, A.L., Ratnikova, L.I., Berteussen, K.A., 1972. On a frequency-time analysis of oscillations. Ann. Geophys. 28, $211-218$.

Levshin, A.L., Yanovskaya, T.B., Lander, A.V., Bukchin, B.G., Barmin, M.P., Ratnikova, L.I., Its, E.N., 1989. Recording, identification and measurement of surface wave parameters. In: Keilis-Borok, V.I. (Ed.), Seismic Surface Waves in a Laterally Inhomogeneous Earth. Kluwer Academic Publishing, Dordrecht, pp. $131-182$.

Levshin, A.L., Ratnikova, L.I., Berger, J., 1992. Peculiarities of surface-wave propagation across central Eurasia. Bull. Seismol. Soc. Am. 82, 2464-2493.

Levshin, A.L., Ritzwoller, M.H., Resovsky, J.S., 1999. Source effects on surface wave group travel times and group velocity maps. Phys. Earth Planet. Inter. 115, 293-312.

Ligdas, C.N., Lees, J.M., 1993. Seismic velocity constrains in the Thessaloniki and Chalkidiki areas (Northern Greece) from a 3-D tomographic study. Tectonophysics 228, 97-121.

Ligdas, C.N., Main, I.G., 1991. On the resolving power of tomographic images in the Aegean area. Geophys. J. Int. 107, 197-203.

Ligdas, C.N., Main, I.G., Adams, R.D., 1990. 3-D structure of the lithosphere in the Aegean Sea region. Geophys. J. Int. 102, 219-229.

Makris, J., 1973. Some geophysical aspects of the evolution of the Hellenides. Bull. Geol. Soc. Greece 10, 206-213.

Makris, J., 1975. Crustal structure of the Aegean sea and the Hellenides obtained from geophysical surveys. J. Geophys. 41, 441-443.

Makris, J.A., 1976. A dynamic model of the Hellenic arc deduced from geophysical data. Tectonophysics 36, 339-346.

Makris, J.A., 1977. Geophysical investigation of the Hellenides. Geophys. Einzelschr. Hamburger 34 (124 pp.).

Makris, J.A., 1978. The crust and upper mantle of the Aegean region from deep seismic soundings. Tectonophysics 46, 269-284.

Martin, L., 1987. Structure et évolution récente de la Mer Egée. Thèse de Doctorat, Paris-Sud, 305 pp.

McKenzie, D.P., 1970. The plate tectonics of the Mediterranean region. Nature 226, 239-243.

McKenzie, D.P., 1972. Active tectonics of the Mediterranean region. Geophys. J. R. Astron. Soc. 30, 109-185.

McKenzie, D.P., 1978. Active tectonics of the Alpine-Himalayan belt: the Aegean Sea and surrounding regions. Geophys. J. R. Astron. Soc. 55, 217-254.

Mountrakis, D., Sapountzis, E., Killias, A., Eleftheriadis, G., Chris- tophides, G., 1983. Paleogeographic conditions in the Western Pelagonian margin in Greece during the initial rifting of the continental area. Can. J. Earth Sci. 20, 1673-1681.

Mueller, St., 1977. A new model of the continental crust. In: Heacock, J.G. (Ed.), The Earth's Crust: Its Nature and Physical Properties. AGU Monograph Series, vol. 20, pp. 289-317.

Panagiotopoulos, D.G., 1984. Travel time curves and crustal structure in the southern Balkan region. PhD thesis, Univ. of Tessaloniki, 159 pp. (in Greek).

Panagiotopulos, D.G., Papazachos, B.C., 1985. Travel times of Pn waves in the Aegean and surrounding area. Geophys. J. R. Astron. Soc. 80, 165-176.

Panza, G.F., 1980. The resolving power of seismic surface waves with respect to crust and upper mantle structural models. In: Cassinis, R. (Ed.), The Solution of the Inverse Problem in Geophysical Interpretation. Plenum, New York, pp. 39-77.

Papazachos, C.B., 1994. Structure of the crust and upper mantle in SE Europe by inversion of seismic and gravimetric data (in Greek). PhD thesis, Univ. of Thessaloniki, Greece.

Papazachos, C.B., 1999. Seismological and GPS evidence for the Aegean-Anatolia interaction. Geophys. Res. Lett. 17, 2653-2656.

Papazachos, B.C., Comninakis, P.E., 1971. Geophysical and tectonic features of the Aegean arc. J. Geophys. Res. 76, 8517-8533.

Papazachos, C.B., Nolet, G., 1997. P and S deep structure of the Hellenic area obtained by robust nonlirear inversion of travel times. J. Geophys. Res. 102, 8349-8367.

Papazachos, B.C., Papazachou, C.B., 1997. The Earthquakes of Greece. Ziti Publ., Thessaloniki, Greece, 304 pp.

Papazachos, B.C., Polatou, M., Mandalos, N., 1967. Dispersion of surface waves recorded in Athens. Pure Appl. Geophys. 67, 95-106.

Papazachos, C.B., Hatzidimitriou, P.M., Panagiotopoulos, D.G., Tsokas, G.N., 1995. Tomography of the crust and upper mantle in Southeast Europe. J. Geophys. Res. 100, 405-422.

Papazachos, B.C., Papadimitriou, E.E., Kiratzi, A.A., Papazachos, C.B., Louvari, E.K., 1998. Fault plane solutions in the Aegean Sea and the surrounding area and their tectonic implications. Boll. Geofis. Teor. Appl. 39, 199-218.

Plomerova, J., Babuska, V., Pujdusak, P., Hatzidimitriou, P., Panagiotopoulos, D., Kalogeras, J., Tassos, S., 1989. Seismicity of the Aegean and surrounding areas in relation to topography of the lithospere-asthenosphere transition. Proc. 4th Inter. Sym. Analysis Seismicity and Seismic Risk, Bechyne Chechoslavakia, Sept. 4-9, 209-215.

Press, F., 1968. Earth models obtained by Monte Carlo inversion. J. Geophys. Res. 73, 5223-5234.

Press, F., 1969. The suboceanic mantle. Science 165, 174-176.

Roussos, N., 1994. Stratigraphy and paleogeographic evolution of the Paleogene Molassic basins of the North Aegean area. Bulletin of the Geological Society of Greece, vol. XXX/2, 275-294. Proceedings of the 7th Congress, Thessaloniki, 25-27 May.

Schwab, F.A., Knopoff, L., 1972. Fast surface wave and free mode computations. In: Bolt, B.A. (Ed.), Methods in Computational Physics. Academic Press, New York, pp. 86-180.

Spakman, W., 1986. Subduction beneath Eurasia in connection with the Mesozoic Tethys. Geol. Mijnb. 65, 145-153. 
Spakman, W., Wortel, M.J.R., Vlaar, N.J., 1988. The Hellenic subduction zone: atomographic image and its dynamic implications. Geophys. Res. Lett. 15, 60-63.

Spakman, W., Van der Lee, S., Van der Hilst, R.D., 1993. Traveltime tomography of the European-Mediterranean mantle down to $1400 \mathrm{~km}$. Phys. Earth Planet. Inter. 79, 3-74.

Vogt, P., Higgs, P., 1969. An aeromagnetic survey of the Eastern Mediterranean sea and its interpretation. Earth. Planet. Sci. Lett. $5,439-448$.

Voulgaris, N., 1991. Investigation of the crustal structure in Western
Greece (Zakinthos-NW Peloponessus area) (in Greek), $\mathrm{PhD}$ thesis, Univ. of Athens, Athens, Greece.

Yanovskaya, T.B., 1997. Resolution estimation in the problems of seismic ray tomography. Izvestia, Phys. Solid Earth 33 (9), $762-765$.

Yanovskaya, T.B., Ditmar, P.G., 1990. Smoothness criteria in surface wave tomography. Geophys. J. Int. 102, 63-72.

Yanovskaya, T.B., Kizima, E.S., Antomova, L.M., 1998. Structure of the crust in the Black Sea and adjoining regions from surface wave data. J. Seismol. 2, 303-316. 